Chapter 6

\title{
Human Papillomavirus Prophylactic Vaccines and Alternative Strategies for Prevention
}

\author{
Lis Ribeiro-Müller, Hanna Seitz and Martin Müller \\ Additional information is available at the end of the chapter
}

http://dx.doi.org/10.5772/55852

\section{Introduction}

First evidence that transmissible agents are involved in the development of cervical cancer dates back to the mid 19th century and is based on investigations of the Italian physician Demonico Rigoni-Stern who recognized that cancer of the womb is found most frequently among women in their fourth and fifth decade and that factors such as age of sexual debut and promiscuity attribute to the risk of acquiring this type of cancer [1]. However, only with the advent of molecular biology in the early 1970s, and after ruling out Herpes Simplex Viruses, a link was established between cervical cancer and infections by certain types of human papillomaviruses (HPV). After isolation of HPV 6 from a condyloma and subsequently of HPV 11 from a laryngeal papilloma the genomic DNA of these two types allowed tracing of other, novel HPVs in biopsies of cervical tumors [2, 3]. The detection of HPV DNA in tumor cells, including the HeLa cell line, was initially met with much doubt and disbelief in the scientific community but could subsequently be confirmed. In fact, the initial observation by Dürst et al. [4] that 11 out of 18 cervical cancer biopsies from German patients were positive for HPV 16 is consistent with today's knowledge of HPV 16 being present in more than $50 \%$ of malignant tumors from the cervix. In the following years the findings by Harald zur Hausen and his colleagues were confirmed by numerous laboratories worldwide and a causative link between HPV infections and cervical cancer in humans was established due to the vast amount of epidemiological studies and an overwhelming body of data obtained in different in vivo and in vitro models. In 2008 Prof. Harald zur Hausen was awarded the Nobel Prize which recognizes his pioneering findings and fundamental role in HPV research. 


\section{HPV vaccines - Early studies in animal models}

The first observations in respect to therapeutic or prophylactic vaccination against papillomaviruses (PV) were made using models of experimental induction of warts in rabbits and humans. In heroic and bold self-experimentation Findlay inoculated himself with wart extracts and noted that he became 'immune' to wart induction. Similarly, Grigg and Wilhelm noted patterns for the appearance of skin warts in school children and attributed their findings to a possible 'resistance' of some individuals [5]. In the first half of the last century a number of efforts were undertaken to treat skin and genital warts by the injection of autologous and heterologous wart extracts; some of these attempts were seemingly met with success [6].

A systematic development of prophylactic papillomavirus vaccines proved difficult without a virus that can be replicated in culture, suitable animal models, and markers for protection. Still, a number of prophylactic vaccine approaches were performed either by the use of formalin-fixed wart extracts or by inactivated purified viruses e.g. in dogs, rabbits, cattle and horses (for review see: [7]). By passive transfer Chambers et al. demonstrated that antibodies confer protection against induction of oral papillomas [8]. One of the first in vitro assays that allowed detection of virus-neutralizing antibodies, the so-called focus-formation assay, was based on transformation of mouse fibroblasts [9]. Initially, this assay was limited to the use of BPV but was later extended to HPV types, by encapsidating the BPV genome in an HPV capsid. Inhibition of virion induced agglutination (HI assay) of mouse erythrocytes by capsid-specific antibodies was employed as a simple surrogate assay before the development of functional reporter-based neutralization assays [10]. The HI assay has intrinsic limitations as it, first, only detects L1-specific antibodies that prevent binding of particles to the cell surface and, second, the nature of the interaction of PV virions with mouse erythrocytes is not well defined. On a different note, it should be mentioned that Kreider and colleagues were the first to develop a functional neutralization assay for HPV 11 by implanting human tissue under the renal capsule of nude mice and subsequently monitoring HPV induced lesions [11]. Because of the complex technique this assay was established only in very few laboratories.

In recent years, the so called pseudovirion-based neutralization assays (PBNAs) have been regarded as the gold standard for the detection of neutralizing antibodies against PVs [12]. These assays have in common that a plasmid encoding a reporter gene (such as secreted alkaline phosphatase, luciferases, fluorescent proteins) is encapsidated in mammalian cells by expression of codon-optimized L1 and L2 genes (Fig. 1). These pseudoviruses can be purified e.g. by gradient centrifugation and used to infect cells in vitro and in vivo. Presence of neutralizing antibodies will prevent infection and thus reporter gene expression. The assay is tedious and does not readily allow for screening of large serum sample collections e.g. for the monitoring of clinical vaccine trials. Recently, we have developed a modified, high-throughput PBNA that allows automated and reproducible detection of neutralizing antibodies (Sehr et al. in preparation). 


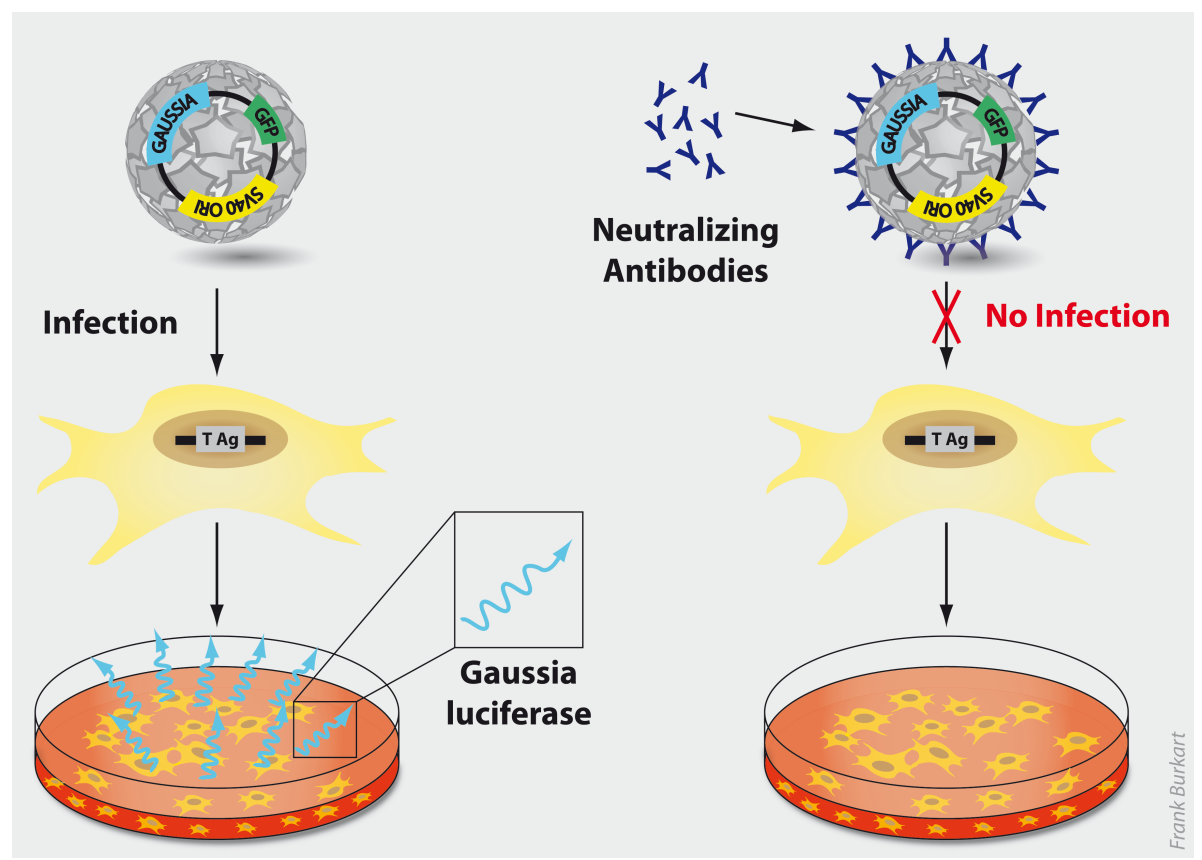

Figure 1. Pseudovirion-based neutralization assay (PBNA). Gaussia = Gaussia luciferase; GFP: green fluorescent protein; SV40 ORI = SV40 origin for replication. Pseudovirions (PSV) encapsidating a Gaussia luciferase reporter gene were produced in mammalian cells and used for infection of HeLa cells. The levels of secreted Gaussia (light blue arrows) can be quantified by a luminescence assay. The presence of neutralizing antibodies (dark blue) abrogates PSV infection and the subsequent secretion of Gaussia.

PV pseudovirions have also been used in a cervicovaginal mouse model for the detection of neutralizing antibodies. In this model, the female mouse genital epithelium is infected with pseudovirions carrying a firefly luciferase gene and luciferase activity is monitored by in vivo imaging. Compared to the in vitro PBNA, the mouse model shows increased sensitivity for the detection of L1 but moreover, of L2 antibodies [13].

\section{Current HPV vaccines}

\subsection{The two commercial HPV vaccines - Similarities and differences}

Many years of research showing that anti-L1 antibodies protect against HPV infection and L1 can assemble into particles called virus-like particles culminated and [14] triggered the development of the current HPV vaccines [15].

Two commercially available prophylactic HPV vaccines, Cervarix ${ }^{\circledR}$ (GSK) and Gardasil® (Merck) have been licensed in over 100 countries. Both are composed of the L1 major capsid protein assembled into non-infectious and highly immunogenic virus-like-particles (VLPs) [16]. 
Cervarix ${ }^{\circledR}$ is a bivalent vaccine containing VLPs from the two most prevalent high-risk HPV types 16 and 18. The VLPs are produced in insect cells and formulated with the adjuvant system AS04 (composed of aluminium hydroxyphosphate sulfate combined with MPL-3-O-deacyl-4'monophosphoryl lipid A) [17]. Gardasil@ is a quadrivalent vaccine that in addition to HPV16 and HPV18 VLPs also contains HPV6 and HPV11 VLPs. These two low-risk types are responsible for nearly $90 \%$ of the genital warts. The VLPs in Gardasil $®$ are produced in a yeast system and adjuvanted with aluminium hydroxiphosphate sulfate salt [18] (Table 1).

\begin{tabular}{|c|c|c|}
\hline Vaccine & Gardasil $^{\circledast}$ & Cervarix $^{\circledast}$ \\
\hline Manufacturer & Merck \& Co., Inc. & GlaxoSmithKline \\
\hline \multirow[t]{3}{*}{ Producer cells } & Yeast & Insect cells \\
\hline & Saccharomyces cerevisiae & Spodoptera frugiperda Sf-9, \\
\hline & CANADE 3C-5 (Stamm 1895) & Trichoplusia ni Hi-5 \\
\hline \multirow[t]{4}{*}{ Antigen } & 20 g HPV6 L1 VLP & $20 \mu \mathrm{g}$ HPV16 L1 VLP \\
\hline & 40 g HPV11 L1 VLP & 20 g HPV 18 L1VLP \\
\hline & 40 нg HPV16 L1 VLP & \\
\hline & 20 mg HPV 18 L1VLP & \\
\hline Vaccination schedule & Months $0,2,6$ & Months $0,1,6$ \\
\hline \multirow[t]{3}{*}{ Package } & Ready-to-use syringe & Ampules \\
\hline & Ampules & $0.5 \mathrm{~mL}$ \\
\hline & $0.5 \mathrm{~mL}$ & \\
\hline Vaccine recommendation & Vaccination of female at age 11 or 12 years & Vaccination of female aged 11 \\
\hline \multirow[t]{2}{*}{ (ACIP) } & (catch-up: $13-26$ years old). & or 12 years old (can be started \\
\hline & Vaccination of male aged 9 through 26 & at 9 years $)$. \\
\hline
\end{tabular}

Modified from [19] and [20]

Table 1. Comparison of the two prophylactic HPV vaccines, Gardasil ${ }^{\circledR}$ and Cervarix ${ }^{\circledR}$.

\section{Safety}

Since the main target groups for the HPV vaccines are children and young women that have not initiated sexual activity, safety was the highest priority for the two vaccine producers.

Over the past years many studies have been conducted to ensure safety and tolerability of Cervarix ${ }^{\circledR}$ and Gardasil ${ }^{\circledR}[21,22]$. Independent of age, sex or ethnicity, the HPV vaccines are highly safe and well tolerated with very little adverse effects and no significant differences between Gardasil® and Cervarix ${ }^{\circledR}$. However, in a direct comparison study between the two vaccines, Cervarix ${ }^{\circledR}$ was associated with higher rates of local injection site reactions than Gardasil@ [23] (Table 2). This effect might be associated with the differences in adjuvant formulation between the two vaccines. 
The most common adverse effects for both vaccines are pain, reddening and swelling at the site of the injection as well as syncope, fatigue, nausea, dizziness and migraine. No severe side effects including auto-immune response abortion or abnormal pregnancy were observed with increased frequency after vaccination with Cervarix ${ }^{\circledR}$ or Gardasil ${ }^{\circledR}$ when compared to the control groups [24-26]

\begin{tabular}{lcc}
\hline Symptom & Cervarix $^{\circledR}$ & Gardasil $^{\circledR}$ \\
\hline Pain & $92.9[90.4,95.0]$ & $71.6[67.5,75.4]$ \\
\hline Redness & $44.3[40.0,48.6]$ & $25.6[21.9,29.5]$ \\
\hline Swelling & $36.5[32.3,40.7]$ & $21.8[18.3,25.5]$ \\
\hline Fatigue & $49.8[45.5,54.2]$ & $39.8[35.6,44.1]$ \\
\hline Headache & $47.5[43.2,51.9]$ & $41.9[37.6,46.3]$ \\
\hline Fever $\geq 39.0^{\circ} \mathrm{C}$ & $0.4[0.0,1.4]$ & $0.0[0.0,0.7]$ \\
\hline
\end{tabular}

Modified from [23]

Table 2. Percentage of women reporting symptoms at least once within seven days after any vaccine dose (total vaccinated cohort) - Einstein et al., 2009 study [23]

\section{Immunity}

\subsection{Immunity of natural HPV infection}

As HPV infection is limited to basal epithelial cells, the virus is normally "hiding" from circulating immune cells during initial stages of infection, limiting the host's immune responses. Additionally, to evade the host's immune system and achieve persistent infection, HPV has developed several mechanisms to down-regulate host immunity $[27,28]$. The virus's success in evading the immune system is corroborated by the finding that of the women infected with HPV, only 50\% develop anti-HPV antibodies (mainly anti-L1). Whether these antibodies can protect against re-incident infection remains unclear.

\subsection{Vaccine induced immunity and duration of protection}

The mechanisms of immunity induced by the HPV vaccines are not fully understood but it seems that humoral immunity (virus-specific neutralizing immunoglobulin $G$ antibodies) plays an important role. Passive transfer of immune serum in pre-clinical animal models, for example, have demonstrated that L1 virus-specific antibodies are sufficient to prevent papillomavirus infection $[14,29,30]$.

Cervarix ${ }^{\circledR}$ and Gardasil ${ }^{\circledR}$ induce production of high levels of anti-L1 antibodies that reach their peak seven months after the administration of the third dose. The level of antibodies gradually decreases over time but even after several years the titers remain higher than in naturally infected women. 


\begin{tabular}{|c|c|c|c|c|c|c|c|}
\hline \multirow[b]{2}{*}{ Vaccine } & \multirow[b]{2}{*}{$\begin{array}{c}\text { Years } \\
\text { (approximate) } \\
\text { after vaccination }\end{array}$} & \multicolumn{6}{|c|}{ Vaccine efficacy $\%(95 \% \mathrm{Cl})$} \\
\hline & & Cohort & $\begin{array}{c}\text { HPV16 } \\
\text { persistent* } \\
\text { infection }\end{array}$ & $\begin{array}{c}\text { HPV } 18 \\
\text { persistent* } \\
\text { infection }\end{array}$ & $\begin{array}{l}\text { CIN2 lesions - } \\
\text { HPV16/18 }\end{array}$ & $\begin{array}{c}\text { CIN3 lesions - } \\
\text { HPV16/18 }\end{array}$ & Reference \\
\hline \multirow{6}{*}{ Cervarix $^{\oplus}$} & 1.5 & $\begin{array}{l}\text { According } \\
\text {-to -protocol }\end{array}$ & $100 \%$ & N/A & - & - & [33] \\
\hline & 3 & $\begin{array}{l}\text { According } \\
\text {-to - protocol }\end{array}$ & - & - & $98.1 \%$ & $100 \%$ & [34] \\
\hline & 4.5 & $\begin{array}{l}\text { According } \\
\text {-to - protocol }\end{array}$ & $100 \%$ & $100 \%$ & $100 \%$ & - & [35] \\
\hline & 5.5 & $\begin{array}{l}\text { According } \\
\text {-to - protocol }\end{array}$ & $100 \%$ & $100 \%$ & $100 \%$ & - & [36] \\
\hline & 7.3 & $\begin{array}{l}\text { According } \\
\text {-to -protocol }\end{array}$ & $100 \%$ & $100 \%$ & $100 \%$ & - & [37] \\
\hline & 8.4 & $\begin{array}{l}\text { According } \\
\text {-to - protocol }\end{array}$ & $100 \%$ & $100 \%$ & $100 \%$ & - & [38] \\
\hline \multirow{3}{*}{ Gardasil $^{\oplus}$} & 3 & $\begin{array}{l}\text { Per protocol } \\
\text { susceptible } \\
\text { population }\end{array}$ & - & - & $100 \%$ & $97 \%$ & [39] \\
\hline & 3 & $\begin{array}{l}\text { Per protocol } \\
\text { susceptible } \\
\text { population }\end{array}$ & - & - & $100 \%$ & $100 \%$ & [40] \\
\hline & 5 & $\begin{array}{l}\text { Per protocol } \\
\text { susceptible } \\
\text { population }\end{array}$ & $96.6 \%$ & $90.6 \%$ & $100 \%$ & $100 \%$ & [41] \\
\hline
\end{tabular}

HPV = Human papillomavirus. According to protocol population = women HPV16 or HPV18 DNA negative during the vaccination schedule, that received 3 doses of the vaccine; Per protocol population = participants received 3 doses of vaccine or placebo within 12 months and were seronegative on PCR analysis for HPV6-, HPV-11, HPV-16, or HPV18 at day 1 through 1 month after the third dose. ${ }^{*}$ Persistent infection correspond to infection detected for $\geq 6$ months. N/A: not available.

Table 3. Cervarix ${ }^{\oplus}$ and Gardasil ${ }^{\oplus}$ efficacy

Both vaccines lead to seroconversion of nearly $100 \%$ of the immunized subjects. Cervarix ${ }^{\circledR}$ was shown to sustain relatively stable immunity against HPV16/18 for more than eight years [31]. Subjects immunized with Gardasil® were shown to be consistently seropositive for more than four years for HPV11, HPV6 and HPV16 but a decline in antibody titers was recorded for HPV18 (from 100\% to approximately 47\%) [32]. However, it cannot be excluded that this observed decline is a result of assay insensitivity. Nevertheless, the protection against HPV18 induced lesions did not decrease suggesting that low levels of anti-HPV18 antibodies are sufficient to confer protection. The Table 3 shows the efficacy of Cervarix ${ }^{\circledR}$ and Gardasil $\AA$ for different clinical trials followed up for different periods of time. 


\section{Efficacy in clinical trials}

Six major clinical trials enrolling around 44.000 females were conducted to evaluate the efficacy of Cervarix ${ }^{\circledR}$ ( 2 trials) and Gardasil ${ }^{\circledR}$ ( 4 trials). Most of the trials included subjects from the age of 15 to 26 years (except for Muñoz et al, 24-45 years) with a limited lifetime number of sexual partners ( $\leq 4-6$, except for Muñoz et al., with no restriction). The sole exclusion criteria were pregnancy and abnormal Pap smears [21, 42-46].

Since cervical cancer is an unethical endpoint for the HPV prophylactic vaccines efficacy evaluation, the clinical trials concentrated on prevention of pre-cancerous high-grade cervical intraepithelial neoplasias (CIN 2 and 3). Results from these trials have shown the high efficacy of the prophylactic vaccines in preventing persistent infection and CIN 2/3 lesions and genital warts for Gardasil ${ }^{\circledR}$ and Cervarix ${ }^{\circledR}$.

\subsection{Cervarix ${ }^{\circledR}$}

The double-blind randomized controlled PATRICIA (PApilloma TRIal against Cancer In young Adults) is the largest Cervarix ${ }^{\circledR}$ vaccine trial performed to date and it was conducted in more than 14 countries from Asia-Pacific, Europe, North America and Latin America. It included over 18.000 healthy women between 15 and 25 years of age with no more than six lifetime sexual partners; these women were enrolled irrespective of their HPV DNA status, HPV serostatus or cytology baseline.

Cervical cytologies and biopsies for 14 oncogenic HPV types were assessed by PCR. The primary endpoint for the vaccine efficacy was the development of CIN 2+ associated with HPV16 or HPV18 and as well non-vaccinated oncogenic HPV types (for cross-protection assessment) [34, 47].

Data from three different cohorts (ATP-E: according to protocol cohort for efficacy vaccinated: $\mathrm{n}=8093$; control: $\mathrm{n}=8069$; TVC: total vaccinated cohort = women receiving at least one dose of the Cervarix ${ }^{\circledR}:$ n=9319; control: $n=9325$; and TVC-naïve = no evidence of oncogenic HPV infection at baseline vaccinated: $n=5822$; control: $n=5819$ ) over a mean of 34.9 months was analyzed. The efficacy of the vaccine against CIN2/3 lesions associated with HPV16/18 was similarly high (around 98\% for CIN2+ and 100\% for CIN3+) in the ATP-E and TVC- naïve cohorts. For the TVC group the efficacy of the vaccine against CIN3+ lesions, irrespective of HPV DNA in lesions, was 30\%.

\subsection{Gardasil ${ }^{\circledR}$}

The randomized, double-blind, placebo-controlled trials FUTURE I and FUTURE II included 18.174 women between 16-26 years of age from 24 different countries from Asia-Pacific, North America, Latin America and Europe. The primary endpoints for the Gardasil@ efficacy clinical trial were a) incidence of genital warts, vulvar or vaginal intraepithelial neoplasia or cancer and b) the incidence of cervical intraepithelial neoplasia CIN2/3 and adenocarcinoma in situ (AIS) lesions [48, 49] 
For the FUTURE II study, which enrolled 12,167 women that were followed for an average of 3 years, Gardasil ${ }^{\circledR}$ efficacy for prevention of HPV-16/18 related CIN3 lesions was $97 \%$ in the per-protocol cohort (population negative for $14 \mathrm{HPV}$ types and receiving all the three doses of the vaccine), $95 \%$ in the unrestricted susceptible population (population receiving one or more vaccination doses) and $45 \%$ in the intention-to-treat cohort (population with or without previous HPV infection). HPV16/11/16/18 related high grade vulvar and vaginal lesions could be prevented with $100 \%$ efficacy by vaccination with Gardasil ${ }^{\circledR}$ in the per-protocol, with $95 \%$ in the unrestricted susceptible, and with $73 \%$ in the intention-to-treat populations. Gardasil® efficacy for prevention of adenocarcinoma in situ was 100\% in the per-protocol susceptible and unrestricted susceptible population and $28 \%$ in the intention-to-treat population. However, one subject in the per-protocol susceptible placebo population developed adenocarcinoma in situ, affecting the reliability of the vaccine efficacy in this group [50].

\subsection{Cervarix ${ }^{\circledR}$ versus Gardasil ${ }^{\circledR}$}

After the data from several clinical trials ensuring safety, tolerability and efficacy of the HPV vaccines was published, discussions began about which vaccine should be implemented in public vaccination programs. To make this decision, the cost-effectiveness of the vaccines, potentially influenced by duration of protection, number of doses required for protection and the extend of cross-protection, needed to be evaluated.

It is a difficult and daunting task to directly compare results from the Cervarix ${ }^{\circledR}$ and Gardasil ${ }^{\circledR}$ clinical trials because of a) differences in the study population and cohorts for testing the vaccine efficacy, $b$ ) differences in the HPV typing and immunological assays and c) differences in the studies' endpoints.

For this reason, an observer-blind study was designed to directly compare the immunogenicity and safety of both vaccines [23]. In this study, a total of 1106 women aged 18 to 45 years were enrolled and vaccinated either with Gardasil ${ }^{\circledR}$ or Cervarix ${ }^{\circledR}$. One month after the third vaccination, sera from all the subjects were collected and the presence of neutralizing antibodies was measured by pseudovirions-based neutralization assay (PBNA). The PBNA showed that all women in both vaccine groups were HPV16 and HPV18 seropositive with the exception of two HPV18 seronegative subjects in the Gardasil@ group.

The titers of anti-HPV16 and HPV18 neutralizing antibodies from serum and cervicovaginal secretions induced by Cervarix ${ }^{\circledR}$ were significantly higher than those induced by Gardasil ${ }^{\circledR}$ in all the tested age strata. The frequency of antigen-specific (HPV16 and HPV18) and memory B-cells were also higher in the Cervarix ${ }^{\circledR}$ than in the Gardasil® group [23].

\subsection{Dose}

Although both vaccines were licensed as 3-dose administrations over six months, this regime has been questioned and re-evaluated either for cost-effectiveness or for difficulties with administering all the doses within the stipulated time frame.

Recently a comparative analysis between the Costa Rica Vaccine Trial cohort was published where it was suggested that two and maybe even one dose of Cervarix® might be as effective 
against persistent HPV16 and HPV18 infections as the three doses [51]. What remains unclear is the duration of protection for the vaccination with fewer doses.

\subsection{Cross-protection}

One surprising finding of the phase II and phase III clinical trials is that both vaccines induce cross-protection against non-vaccine HPV types.

A recent end-of-study analysis of the Cervarix ${ }^{\circledR}$ PATRICIA clinical trial, performed after 48 months of follow-up, evaluated the cross-protection against non-vaccine HPV types in persistent infection and high grade CIN2+ and CIN3+ lesions. In summary, this analysis reports consistent vaccine efficacy against HPV31, HPV33 and HPV45 for all the end-points [52]

The analysis of combined data from the Gardasil ${ }^{\circledR}$ FUTURE I and FUTURE II clinical trials reveals that vaccination reduced the rate of HPV-31/33/45/52/58 infection, CIN1-3 and AIS. However the reduction of HPV-31/33/45/52/58 related CIN2 lesions was not significant [53]

A meta-analysis study suggests that cross-protection efficacy against persistent HPV infection and CIN2 lesions is higher for Cervarix ${ }^{\circledR}$ than for Gardasil@. While Gardasil@ can confer protection against the non-vaccine type HPV31, Cervarix ${ }^{\circledR}$ can efficiently protect against HPV 31, HPV 33 and HPV45. This study evaluated comparable populations in different clinical trials that used different methods to identify efficacy endpoints (e.g. genotyping of HPV to determine HPV persistent infection). The sensitivity of the methods used in clinical trials and population differences can influence the comparison between Cervarix ${ }^{\circledR}$ and Gardasil@[54].

A sub-analysis of an observer-blind study, performed to allow a direct comparison between Cervarix $\AA^{\circledR}$ and Gardasil $\AA^{\circledR}$, evaluated cross-protection against non-vaccine HPV types for both vaccines. This study confirmed that both vaccines induce cross-reactive responses against HPV31 and HPV45 but that the responses were initially much lower for the Gardasil® vaccinated group. However, after 24 months the level of humoral responses for HPV31/45 was equally low for both vaccines. The only considerable difference between the vaccines shown in this study is the higher levels of T-cell response with the Cervarix ${ }^{\circledR}$ vaccine. Whether or not the $\mathrm{T}$ cell response is necessary for cross-protection remains unclear [55].

All the studies show lower levels of non-vaccine HPV antibody titers compared to the typespecific titers. One possibility to be considered is that the cross-protective responses will wane with time. There are on-going efforts in current phase IV surveillance studies addressing the degree and durability of cross-protective responses.

\section{Age for HPV vaccination}

\subsection{Preadolescent girls and young women}

Vaccination with Gardasil ${ }^{\circledR}$ or Cervarix ${ }^{\circledR}$ does not lead to clearance of pre-existing HPV infections [56]. Considering the decreasing age of sexual debut in many countries, both vaccines target preadolescent girls and young women. The Advisory Committee on Immunization Practices (ACIP) recommend vaccination of females aged 13 to 26 years for Cervarix ${ }^{\circledR}$ and vaccination of 9 to 26 year old males and females for Gardasil@ $[57,58]$. 
Most of the clinical trials performed to evaluate efficacy of the prophylactic vaccines included subjects older than the primary target population. This is explained by a) the need of a population where the HPV infection happens at higher frequency for efficacy proof-ofprinciple purposes and b) legal and ethical limitations regarding the evaluation of sexual activity in the preadolescent population.

A Cervarix ${ }^{\circledR}$ clinical trial, performed in Denmark, Estonia, Finland, Greece, Netherlands and Russia, with an extension study (4 years follow-up) conducted in Denmark, Estonia and Finland, was designed to evaluate safety and immunogenicity of the bivalent vaccine in two age groups (10-14 and 15-25 years). According to the follow-up study, Cervarix $®$ induced higher systemic and mucosal immune responses, which sustained for more than four years, in the 10-14 years group compared to the 15-25 years group [59].

\subsection{Older women}

Women can acquire HPV infections at any age. However, epidemiological data report that the highest prevalence of HPV infections occur in sexually active women under 25 years of age and decline with age progression [60].

Recent meta-analysis studies have been showing a second peak of HPV prevalence in women over 44 years [61]. There are several hypotheses explaining this phenomenon but the most plausible one is associated with changes in sexual behavior of women and their partners at this age.

Humoral responses to HPV vaccines are known to decrease gradually with age progression but the antibody levels remain several fold higher for years in vaccinated (46-55 years) than in non-vaccinated subjects who developed natural immunity in response to infection [62]. A recent analysis of the FUTURE I and FUTURE II clinical trials evaluated the efficacy of Gardasil ${ }^{\circledR}$ in HPV DNA positive women who were treated for cervical, vulvar, or vaginal disease. This study showed that vaccination with Gardasil@ decreases by more than $40 \%$ the incidence of subsequent HPV-related diseases including genital warts and CIN1/2 lesions, irrespective of the HPV type in the lesion [63]. This finding suggests that including women older than 26 years in the vaccination program might prevent HPV persistent infection in naïve women and reduce re-infection for those that were already infected.

\subsection{Vaccination of males}

HPV infection of males is associated with genital warts, anogenital cancer, oral cancer, and recurrent respiratory papillomatosis. The overall incidence of HPV infection is very similar for men and women, although, in contrast to the situation in women, HPV infection in males does not seem to be age related [64].

Currently, Gardasil@ is the only HPV prophylactic vaccine licensed for use in males. Their target population is boys and men aged 9 to 26 years. Its high immunogenicity, safety and efficacy against anogenital warts and perianal/perineal intraephitelial neoplasia in males has been reported in several clinical trial studies $[65,66]$. 
Even though several mathematical models suggest that the inclusion of males in vaccination programs will not be a cost-effective strategy [67], the potential reduction of the health burden associated with HPV infection in males (e.g.: anal cancer and anogenital warts) and the possibility to reduce the risk of HPV transmission to women argue in favor of extending HPV vaccination programs to males.

One of the arguments against the vaccination of males is that immunization of females might already lead to enhanced herd immunity and thereby reduce male lesions as well. One factor not considered with this argument is the scenario of men who have sex with men (MSM) who cannot benefit from female vaccination.

The MSM population is one of the most affected by HPV warts and anal cancer. It is clear that this population will not benefit from female vaccination. Recently, a clinical trial enrolling 602 healthy men who have sex with men (16 to 26 years of age) showed efficacy and safety of Gardasil@ against high-grade anal intraepithelial neoplasia (AIN2/3) [68].

Based on data of Gardasil® safety, efficacy against AIN2/3, estimates of disease and cancer resulting from HPV and cost-effectiveness, the Advisory Committee on Immunization Practices (ACIP) recommended routine use of the quadrivalent $\mathrm{HPV}$ vaccine in males aged 11 or 12 years [58].

\subsection{Vaccination of immunocompromised}

Immunocompromised women and men are known to have higher incidences of HPV infection and HPV-related diseases including cervical and anal cancer. However, little is known about the efficacy and safety of the prophylactic vaccine in this population.

Few HPV clinical trials have been studying HIV positive populations. Among those, a clinical trial evaluated Gardasil@ safety and immunogenicity in HIV infected children from 7 to 12 years, separated into three different groups according to their CD4+ T cells count. The vaccine was considered highly safe, with no CIN3 lesions being observed in the vaccinated group when compared to the control. Vaccination led to seroconversion of $99 \%$ of the immunized subjects; however, antibody titers for HPV16 and HPV18 were much lower $(30-50 \%)$ than for the historical control (HIV uninfected children - Gardasil@ vaccinated) [69], indicating a reduced response in this target population.

As levels of HPV16 and HPV18 antibodies were still comparable to HIV-uninfected women (16-26 years old) in whom the vaccine efficacy was confirmed, long-term studies with more subjects are necessary to determine vaccine efficacy in the HIV infected population.

\section{Is there room and need for second generation vaccines?}

As outlined above, the two commercial vaccines induce long lasting high titer, protective antibody responses against the HPV types included in the vaccines. The efficacy of preventing vaccine type induced lesions can reach up to $100 \%$. This success is based on the exceptional 
immunogenicity of HPV virus-like-particles and the current vaccination programs will surely have significant impact on reducing the HPV associated cancer burden in the near future. Still, there are several shortcomings of the commercial vaccines which include costly production, need for invasive administration, low stability requiring intact cold chains in vaccine delivery and a narrow range of protection limited mainly to vaccine type papillomaviruses. Further, studies have shown that vaccination with the commercial vaccines has no impact on the progression of pre-existing lesions, i.e. neither Gardasil® nor Cervarix ${ }^{\circledR}$ seem to have a therapeutic effect [56]. Although basically all vaccines used in routine medicine are of prophylactic nature, this was not necessarily expected to be the case for the HPV VLP vaccines. In a number of preclinical studies it was demonstrated that vaccination of mice with VLPs induces strong cytotoxic T-cell responses against the L1 antigen and in case of L1-E7 chimeric particles also against the E7 portion [70-73]. The response had strong anti-tumorigenic properties in different tumor challenge models. Therefore, there was reason to hope for a vaccination benefit for humans already infected with the corresponding HPV type. Unfortunately, however, this benefit was not observed in clinical trials to date.

To overcome at least some of the limitations of the commercial vaccines a number of different approaches to develop a second generation PV vaccine are followed, some of which will be addressed in more detail below.

\section{Second generation vaccines targeting $\mathrm{L1}$}

Both current commercial vaccines show excellent safety and efficacy profiles and there seems to be little room for improvement in either aspect when addressing the HPV type-specific protection. Some countries are considering or are in the process of implementing a two dose regiment, driven by the intention to minimize costs [74, 75]. Such deliberations would benefit from higher immunogenicity of the VLP vaccine, which could possibly be achieved by using stronger adjuvant systems. But naturally, it seems unlikely that Merck or GSK would find a sufficient economical motivation to move along this road. What's more, there is only a limited repertoire of adjuvants that can be used in prophylaxis for a young target population.

Both Merck and GSK are probably not highly motivated in developing second generation HPV vaccines that would compete with their blockbusters. An exception is the nonavalent HPV VLP vaccine that is currently evaluated by Merck in clinical trials. A number of pre-clinical studies focused on the development of L1-based vaccines that overcome one or more of the limitations discussed above. These second generation approaches addressed delivery (e.g. oral), production systems (plant, E. coli), stability (e.g. capsomeres) and extension to therapeutic applications (chimeric L1 proteins) [76-78]. In light of the fact that the current VLP vaccines are inducing a limited degree of cross-protection, for which the nature is not yet known, one could envision modifying the L1 protein so as to extend the breadth of protection, but to our knowledge, this strategy is currently not pursued.

As indicated above, the protective range of Cervarix ${ }^{\circledR}$ and Gardasil® is mainly limited to the vaccine type papillomaviruses. In their clinical trial GSK could show that immunization with 
Cervarix ${ }^{\circledR}$ induces cross-protection against additional types such as HPV 31, 33 and 45 and Gardasil ${ }^{\circledR}$ induces protection against HPV 31, albeit at lower efficacy. As a consequence, in 2010 the European Medicines Agency has approved the amendment of the license of Cervarix ${ }^{\circledR}$ in prevention of HPV 31, 33 and 45 induced lesions. The molecular mechanisms for the enhanced cross-protection of Cervarix ${ }^{\circledR}$ in comparison to Gardasil ${ }^{\circledR}$ is not fully understood. One explanation could be the fact that Cervarix ${ }^{\circledR}$ is inducing higher titers against HPV 16 and HPV 18, possibly due to the stronger adjuvants used in the formulation of Cervarix ${ }^{\circledR}$. Another explanation could be structural differences of the VLPs contained in the two vaccines.

However, despite this extended cross-protection observed for Cervarix® about 20\% of cervical cancer cases remain uncovered by the vaccine. To breach this gap, Merck MSD is currently evaluating a nonavalent HPV VLP vaccine in phase III clinical trials. In addition to the nononcogenic HPVs 6 and 11, this vaccine includes VLPs of HPV types 16, 18, 31, 33, 45, 52 and 58 and theoretically would reach close to $88 \%$ efficacy. It remains to be determined whether this cocktail of nine different VLPs is able to induce prolonged protective responses against the corresponding HPV types or if due to interference this may not be possible. Further, because of increasing vaccine complexity this strategy will be limited due to rising costs in production. Also, it will be difficult to prove vaccine efficacy in preventing cervical dysplasia induced by rather rare HPV types, such as HPV 52 and HPV 58, if neutralizing antibodies or at least prevention of infection by these types are not accepted as surrogate markers by the licensing agencies.

\section{Examples for second generation L1-based vaccines}

\subsection{Genetic vaccination}

There are more than 200 different papillomaviruses infecting vertebrates. Among them are roughly 50 types for which there is a theoretical interest of implementing prophylaxis and these include oncogenic HPVs, skin type HPVs relevant in immune compromised patients, bovine PV infecting cattle [79] and horses and PV viruses infecting pets. It has been shown in a number of studies that genetic vaccination with codon-adapted L1 genes leads to the induction of high titer neutralizing antibodies. Vaccination has been performed by intramuscular needle injection or by the use of a gene gun [80-90]. We observed particularly strong neutralizing antibody responses when administering codon-modified L1 genes using a tattooing device [84, 91]. In addition to delivering the expression constructs to muscle and/or antigen presenting cells, tattooing induces a certain degree of local tissue damage which might serve as a danger signal $[92,93]$. The great advantage of immunization with naked DNA is the ease of constructing and producing the vaccine vectors for many different L1 antigens since standardized procedures can be applied. Also, DNA is a very stable molecule making the need for intact cold chains in vaccine distribution obsolete. In addition, it has been shown that cocktails of different L1 expression constructs can be applied to mount a broad range of protection, although some kind of interference between different L1s has been observed [94]. 
Currently, no clinical testing involving human subjects is being performed with naked DNA or with a genetic vector. For one, DNA immunization has not found its way to human immune prophylaxis to date. The main reason is the much lower efficacy of DNA vaccines in primates compared to the murine system. Further, there are concerns about the safety of DNA vaccines in general. Although these concerns are of theoretical nature only, they still pose a major hurdle for application in routine vaccine prophylaxis.

The ease of targeting multiple L1 antigens has also been a motivation to evaluate viral vector based genetic approaches. Different viral vectors have been used and these include vaccinia virus, vesicular stomatitis virus, and adenoviruses [95-98]. High titer neutralizing antibody responses were induced in vaccinated mice. Additionally, in some of the studies strong cellular immune responses against the L1 antigen could be demonstrated. Using the cottontail rabbit papillomavirus model, it was shown that single intranasal administration of recombinant vaccinia virus [99] or vesicular stomatitis virus (VSV) [96, 97] induces anti-L1 antibodies and protections against CRPV challenge, although the latter could also have been a consequence of the induction of cellular immune responses against L1.

Berg et al. ([98] [100] produced correctly folded canine oral PV VLPs using recombinant adenoviruses. Immunization of mice led to high titer neutralizing antibody responses, but the recombinant adenoviruses have not yet been tested in the COPV challenge model.

When considering administration, the use of complex virus systems including vaccinia virus, VSV and adenoviruses faces significant safety issues. Moreover, most vaccinations will likely be limited to single administration due to the strong responses against the vectors. In this light it might not be possible to generate responses against L1 proteins of multiple PVs.

Adeno-associated virus (AAV) vectors combine the simplicity of naked DNA with the efficacy of viral vector gene delivery. AAV vectors are extremely stable and can be lyophilized without compromising their transduction activity. Also, these viral vectors do not encode for viral gene products. We have used AAV vectors for intranasal and systemic delivery of the L1 gene. Single doses of AAV-L1 induce long lasting (>1 yr) neutralizing antibody responses in mice. The intranasal application also induced mucosal antibodies and cellular immunity. Non-adjuvanted intranasal application in macaques with recombinant AAV9 vectors also induced immunity against the encoded L1 antigen [101-104]. Liu and colleagues reported on the co-administration of AAV-L1 vectors together with a recombinant adenoviruses encoding for granulocyte macrophage colony-stimulating factor [105]. This strategy yielded higher neutralizing titers compared to VLP immunization but might prove difficult in translating into application in humans.

In addition to viral vectors, L1 has also been delivered by live prokaryotic vectors such as Salmonella enterica Typhii [106-109] and recombinant Bacille Calmette-Guerin (rBCG) [110, 111]. Nardelli-Haefliger was the first to demonstrate that live L1-recombinant bacteria (S. typhii) induced mucosal and systemic antibody responses in mice. In another study, Govan et al. showed that rabbits vaccinated with rBCG encoding the CRPV L1 protein are protected against viral challenge [110]. This protection might, however, in part be due to cellular immune 
responses against the L1 antigen, although the authors could demonstrate in vitro neutralization activity of the rabbit sera.

\section{Alternative production systems}

The current HPV vaccines are produced either in yeast (Gardasil@) or insect cells infected with recombinant baculoviruses (Cervarix $\left.{ }^{\circledR}\right)$. It is not disclosed by the vaccine manufacturers what the production costs per dose really are, but insect cells present a rather complex platform and yeast cells provide challenges in the extraction procedures. In the early phases of HPV VLP technology, several labs worked on expressing L1 in E. coli but only recently has it been possible to produce properly folded L1 in this system. It was Chen et al. who showed in 2001 that Nterminally modified L1 protein of HPV 11 and 16 can be expressed in E. coli and purified in the form of native pentamers (capsomers) [112]. Yuan and colleagues reported that two doses of $400 \mathrm{ng}$ of a GST-L1 fusion protein, assembled in capsomere-like structures protected dogs from a challenge with COPV. HPV 16 L1 pentamers share essential conformational epitopes with VLPs [113, 114]. L1 pentamers are less immunogenic compared to VLPs but use of appropriate adjuvant systems (e.g. ASO4) can largely compensate for this [113]. In addition to being produced cost-effectively in E. coli, L1 pentamers are also more stable than VLPs making an intact cold-chain in vaccine distribution obsolete. Although clinical trials are in preparation, efficacy of L1 pentamers has not yet been assessed in human subjects. However, Stahl-Hennig could show capsomeres adjuvanted with synthetic double stranded RNA, either poly ICLC or poly IC induced strong anti-L1 antibody and T-helper responses in rhesus macaques [115].

In a number of studies the production of L1 antigens in transgenic plants has been evaluated. Earlier studies showed that the surface antigen of hepatitis B virus can be expressed and assembled in transgenic plants [116]. Importantly, oral delivery of unprocessed plant material induced HBsAg specific immunity in mice and healthy volunteers [117]. This report ignited the idea that vaccine antigens can be produced with the aid of transgenic plant technology. The great advantage of plants is the simplicity by which vast quantities of biomass can be produced with all required technology already in place. Bypassing the requirement for antigen extraction and purification would allow to meet the worlds growing, yet unmet, demand for cheap vaccines. In this light, production of L1 in plants was initiated, [118-128], and immunogenicity after either oral or systemic delivery was confirmed. Yield of L1, which initially posed a major problem, improved significantly to more than $10 \%$ of the total soluble protein [125].

Today's consensus on antigen production in plants stresses standardized extraction and purification to ensure antigens with defined properties and limited inter-batch variability will be an essential criteria. Also, much of the L1 antigen in the plant tissue is incorrectly folded and hence has only little immunogenicity. Overall, there are strong resentments by regulatory agencies and vaccine manufacturers on introducing poorly standardize-able oral vaccines originating from partially processed plant material.

In summary, there are tremendous hurdles that novel second generation vaccines based on the L1 antigen must be overcome starting with facing and competing with the two existing 
commercial vaccines. The main challenge seems to be the need for demonstrating noninferiority. Licensing of Gardasil ${ }^{\circledR}$ and Cervarix ${ }^{\circledR}$ has been a mammoth task, involving tens of thousands participants in clinical trials. It is very unlikely that such evaluation can be reproduced with a vaccine approach that presents only an incremental improvement in one of the other shortcomings of Gardasil ${ }^{\circledR}$ and Cervarix ${ }^{\circledR}$. Other equally important issues are safety and simplicity of second generation vaccines, especially in light of the target population's young age. Lastly, intellectual property is an important factor in vaccine development. While the tight patent situation on L1 VLP technology might eventually be less stringent in the coming years, this will also leave novel developments without sufficient protection, making major investments for manufacturers less attractive.

\section{L2: Candidate for a potential pan HPV vaccine?}

At the time when PV VLP technology started to have its major impact on papillomavirus research and vaccine development, the group of Saveria Campo in Glasgow reported that vaccination of cattle with a bacterially produced minor capsid protein L2 induced protection against challenge with infectious BPV 4 virus [129]. The authors identified epitopes located in a region of L2 encompassing amino acids 131-151 of BPV 4. Although the report describes these epitopes as B-cell epitopes, no neutralization assay could be performed at the time and hence an involvement of cellular immunity could not be ruled out. Also, the antigens that were either GST-L2 fusion proteins or conjugated peptides were of rather poor immunogenicity. As the field was moving towards VLP vaccines that induce very strong protective effects, L2 was not given further thought as a vaccine antigen at the time.

Later, Richard Roden and his colleagues investigated in detail the suitability of L2 as a vaccine antigen. They observed that L2 antigens purified from E. coli induced cross-neutralizing antibodies as assessed by the focus formation assay developed by the investigators [130]. Subsequently, they mapped a cross-neutralizing epitope to a region spanning amino acids 1-88, which was later pin-pointed to amino acids 17-36 [131-133]. Interestingly, human sera from a therapeutic vaccine study using a L2-E6-E7 fusion protein produced in E. coli (TA-CIN; [134]) came back positive for neutralizing activity [132].

The presence of neutralizing and cross-neutralizing epitopes in the N-terminus of L2 was reported and confirmed by others. Kondo and colleagues mapped several regions in the L2 protein between amino acids 1-140 [135]. Some of the neutralizing epitopes were later confirmed by others, however it seems clear today that only one epitope, comprising amino acids 17-36, consistently elicited cross-protection [136-138].

After identifying the target region in the L2 protein, the major challenge in developing L2 as a vaccine antigen was posed by L2's low immunogenicity compared to L1. No or very little neutralizing activity is induced when fragments or peptides of L2 are used as antigens [129, 137]. Further, VLPs composed of L1 and L2 do not induce measurable anti-L2 responses. Because of this, a number of strategies were pursued with the goal of increasing immunogenicity of the L2 cross-neutralizing epitope. 
Alphs et al. observed a strong increase in immunogenicity of the 17-36 epitope when conjugating the L2 peptide to a synthetic lipopeptide (TLR2 agonist) and a broadly acting T-helper epitope [139]. This antigen induced rather high neutralizing titers against HPV 16 while responses against other high-risk HPVs including HPV 18 or HPV 45 were 1-2 orders of magnitude lower. Still, this fully synthetic L2 vaccine provided an elegant basis for the development of a L2 vaccine. Jagu et al. reported that a concatenated L2 fusion protein, consisting of the amino acids 11-88 of five different HPV types induced strong neutralization and cross-neutralization and was superior compared to monotypic HPV 16 L2 antigen. This approach is expected to enter a clinical phase in 2013.

Displaying the 17-36 epitope on bacteriophage PP7 capsids was shown to be an attractive alternative approach in generating a functional L2-based vaccine [140,141]. VLPs of bacteriophage PP7 can be produced in large quantities and are tolerant for the insertion of heterologous peptides. Immunization of mice leads to high titers of ELISA reactive L2-specific antibodies. Cross-protective neutralization of HPV pseudovirions was shown in an in vivo challenge model. The authors did not titrate the sera in an in vitro neutralization assay and thus it is not clear how robust the anti-L2 responses were.

A 'natural' scaffold for the presentation of L2 epitopes would be to insert the cross-neutralizing epitope into L1 loops located on the VLP surface. This would provide for a highly repetitive presentation of the L2 region. Schellenbacher et al. pursued this approach and tested various peptide insertions into the BPV1 and HPV 16 L1 protein [142]. Such insertions often interfere with proper assembly of the L1 into higher ordered structures but the authors were able to produce and purify a number of L1-L2 chimeric particles. They demonstrated that the CVLPs still induced L1-specific neutralization, indicating mostly correct conformation of the L1 protein. More importantly, chimeric particles carrying the 17-36 epitope of HPV 16 L2 induced neutralizing antibody responses in rabbits against HPV 5, 11, 16, 18, 45, 52, 58 pseudovirions with titers ranging from 1:100 to $1: 10,000$.

Recently, we have developed a strategy to boost the immunogenicity of the L2 cross-neutralizing epitope by using bacterial thioredoxin ( $\operatorname{Tr} x)$ as a carrier [137]. Due to its rigid structure, this small, 109 amino acid long protein can constrain rather large multi-peptide insertions of heterologous antigens without compromising carrier structure. Previously, presenting an amyloid- $§$ peptide in context of an E. coli Trx scaffold allowed induction of Aß immune responses in a mouse model for Alzheimer [143]. When we inserted the HPV 16 L2 crossneutralizing epitope (aa 20-38 corresponding to 17-36 described by Roden et al.) we achieved a boost in immunogenicity by several orders of magnitude, compared to the peptide linked to keyhole limpet hemocyanin. Further, multimerization of the L2 epitope in the Trx led to further increase in induction of neutralizing antibodies. While we also confirmed the existence of other regions in the L2 N-terminus as targets for neutralizing antibodies, we only found crossneutralization for the 20-38 epitope [136]. We also found that a subset of antibodies reactive against the different L2 epitopes fail to neutralize HPV pseudovirions in vitro and this might be due to steric hindrance of L2 epitope recognition in the context of virus capsids.

Ultimately, there is convincing evidence that the L2 protein of HPV contains a number of neutralizing epitopes and importantly one major cross-neutralizing epitope. It is also clear that 
due to the low immunogenicity of L2 an appropriate scaffold and/or adjuvant system is required. Still, there are several issues to be addressed. First, no systematic comparison of the different strategies of L2 epitope presentation has been carried out. No consensus has been reached as to which parameters for L2 vaccination would be an indicator for vaccine efficacy or would present a correlate for protection in vivo. Currently, there are a number of different assays to determine L2-directed humoral immune responses. Although anti-L2 antibodies can be readily measured by ELISA assays, this does not provide a meaningful result, as many antibodies recognizing the neutralizing epitopes seem to be non-functional. Typically, ELISA titers are orders of magnitude higher compared to titers obtained in functional neutralization assays.

\section{Approaches to measure induction of neutralizing antibodies}

A nowadays routine assay is the pseudovirion-based neutralization (PBNA) assay developed by Buck et al. that measures transduction efficiency of PV capsids encapsidating a reporter gene. In the presence of L1 or L2 neutralizing antibodies or compounds that interfere with virus infection such as carrageenan (see below), transduction of cells is inhibited. This assay is considered the gold-standard for in vitro assays and (theoretically) measures any antibody that prevents binding, uptake, uncoating and trafficking of viruses. Although the PBNA has been routinely used for the detection of L2-directed neutralization, recently, Day et al. described a modified in vitro neutralization assay with increased sensitivity for L2- (and L1-) specific neutralizing antibodies [144]. In this assay, the virus is treated with exogenous furin convertase afterinducing a conformational change. Furin has been shown to beessential for PV infection and the L2 proteins have a conserved cleavage site at their N-terminus. Cleavage of L2 is a prerequisite for the binding of antibodies to themajor cross-neutralizingepitope17-36. Typically, the L2-specific titers in the L2-PBNA are at 10-100 fold higher compared to the standard PBNA.

As described above, early vaccination experiments have been carried out in rabbits and cows, followed by challenge with the corresponding virus, CRPV or BPV. Readout was induction of papillomas. The CPRV model was extended for the use of HPV by 'pseudotyping', i.e. encapsidating CRPV genomes into HPV 16 capsids. By this, rabbits can serve as an in vivo model for testing HPV vaccine antigens. Protection against oral papillomas in dogs infected with the canine oral papillomavirus was an essential milestone to demonstrate that VLPs can induce sterilizing immunity against PV infection. Also, by passive transfer it could be shown that antibodies are sufficient for protection.

However, despite the highly valuable contribution of BPV, CRPV, and COPV models, only a few laboratories around the world had the available means and resources to establish them for routine use.

The laboratory of John Schiller developed a mouse model for PV infection that can find widespread routine application more easily [13]. In this model, the genital mucosa is infected with pseudovirions encapsidating a luciferase reporter gene. Infection can be quantified by in vivo imaging. For efficient infection, microtraumata are induced into the mucosal epithelium, 
either mechanically or chemically. Vaccine antigens can be analyzed directly, i.e. by immunizing the mice before performing the challenge or indirectly by a passive transfer of antibodies from immunized animals or even humans. This model has later been translated to macaques. In one interesting study it was demonstrated that cytology specimen collection carried out in the macaques, as performed in routine pap screening in women, increases the likelihood of infection by papillomaviruses [145], which, in return, can be prevented by the use of carrageenan in the lubricant which is used in the pelvic exam.

Interestingly and similar to the L2-PBNA, the in vivo challenge model shows increased sensitivity compared to the standard PBNA. In fact, we have learned from these assays that extremely low amounts of L2-specific antibodies, which were not detected by the standard PBNA, are sufficient for protection in vivo in mice. It is not clear, whether this is due to the same mechanisms, e.g. better access of the L2 neutralizing epitopes. Further, it should be noted that it is not certain whether the increased sensitive of the L2-PBNA or the in vivo challenge model correlate with protection in vivo in humans.

The existing animal models are unlikely to make functional in vitro assays obsolete. First, they are not suited for analyzing large sets of samples and also, it is difficult to produce quantitative estimates of protection as they allow only very limited titration of sera.

\section{Alternative strategies for HPV prevention}

Concerns about the limitation of the HPV vaccines (e.g.: type specificity and costs) stimulate constant research on alternative strategies for HPV prevention.

Condoms, spermicides, microbicides, circumcision and contraceptives are included in the extensive list of preventive measures that have been shown to curb HPV infection and persistence.

Condoms are known to be protective against many sexual transmitted diseases such as HIV, gonorrhea, chlamydia and tricomoniasis. However, a cross- sectional analysis conducted in men (18-70 years old) from Brazil, Mexico and United States, showed that HPV infection can be reduced but not completely prevented by the use of condoms. Several factors can be attributed to the low efficacy of condoms in preventing HPV infection, including inappropriate usage leading to condom breakage and slippage and the fact that condoms cannot cover all the HPV infected genital areas [146].

Circumcision has been reported to play a role in preventing sexual transmission of HIV, herpes simplex and HPV [147-149]. A recent trial reported that circumcised males have a reduced prevalence of oncogenic HPV types by $32 \%$ to $35 \%$ and that this effect might be transferred to the partners of circumcised men [150]. Even though the positive effect of the circumcision against HPV persistence has been confirmed by several studies [151-153], ethical issues and complications make circumcision a procedure that most likely will not be routinely adopted.

Different microbicides have been studied for their properties to protect against sexual transmitted infections (STIs). Among those, the spermicide the nonoxynol-9 (N-9) was the most 
promising. This spermicide, largely available in the market during the 90s, has shown to be protective in vitro against several STDs as gonorrhea, candidiasis, herpes simplex and HIV [154-157] However, clinical trials showed that in vivo N-9 was not protective against HIV and HPV and could even promote higher infection ratio due to inflammatory and toxicity effects $[13,158]$.

Carrageenan is a sulfated polysaccharide compound routinely used as thickening ingredient in food products as well as in sexual lubricants and therefore has an excellent safety record. It is derived from seaweed and studies have shown that it confers protection against HIV and HPV in vitro $[159,160]$. In a phase III clinical trial, carrageenan did not show any effect against HIV but it was tolerable and safe [161]. However, carrageenan was shown to confer HPV protection in a murine animal challenge model [162] and to minimize the increased susceptibility to HPV infection during or after cytology screening in rhesus monkeys [163].

Recently, a dendrimeric gel microbicide (VivaGel - SPL7013) was developed by Starpharma for prevention of infections by HIV and HSV-2. The efficacy and safety of the gel have been demonstrated in vitro and in in vivo in animal models [164]. Several clinical trials to evaluate the gel safety, tolerance and efficacy are ongoing. In 2008 Starpharma announced that their product can inhibit HPV infection in in vitro assays [165].

\section{Acknowledgements}

We would like to acknowledge Frank Burkart for designing figures.

\section{Author details}

Lis Ribeiro-Müller, Hanna Seitz and Martin Müller

German Cancer Research Center (DKFZ), Program Infections and Cancer, Heidelberg, Germany

\section{References}

[1] Rigoni S. Fatti statisici relativi alle malatie cancerose. G Serve Prog Pathol Terap. 1842;2:507-17.

[2] Gissmann L, Wolnik L, Ikenberg H, Koldovsky U, Schnurch HG, zur Hausen H. Human papillomavirus types 6 and 11 DNA sequences in genital and laryngeal papillomas and in some cervical cancers. Proceedings of the National Academy of Sciences of the United States of America. 1983 Jan;80(2):560-3. 
[3] de Villiers EM, Gissmann L, zur Hausen H. Molecular cloning of viral DNA from human genital warts. Journal of virology. 1981 Dec;40(3):932-5.

[4] Dürst M, Gissmann L, Ikenberg H, zur Hausen H. A papillomavirus DNA from a cervical carcinoma and its prevalence in cancer biopsy samples from different geographic regions. Proceedings of the National Academy of Sciences of the United States of America. 1983 Jun;80(12):3812-5.

[5] Grigg WK, Wilhelm G. Epidemiological study of planter warts among school children. Public health reports. 1953 Oct;68(10):985-8.

[6] Biberstein. Immunization therapy of warts. Arch Dermatol Syphilol. 1943;50:12-22.

[7] Nicholls PK, Stanley MA. The immunology of animal papillomaviruses. Veterinary immunology and immunopathology. 2000 Feb 25;73(2):101-27.

[8] Chambers VC, Evans CA, Weiser RS. Canine oral papillomatosis. II. Immunologic aspects of the disease. Cancer research. 1960 Aug;20:1083-93.

[9] Roden RB, Greenstone HL, Kirnbauer R, Booy FP, Jessie J, Lowy DR, Schiller JT. In vitro generation and type-specific neutralization of a human papillomavirus type 16 virion pseudotype. Journal of virology. 1996 Sep;70(9):5875-83.

[10] Roden RB, Hubbert NL, Kirnbauer R, Breitburd F, Lowy DR, Schiller JT. Papillomavirus L1 capsids agglutinate mouse erythrocytes through a proteinaceous receptor. Journal of virology. 1995 Aug;69(8):5147-51.

[11] Howett MK, Kreider JW, Cockley KD. Human xenografts. A model system for human papillomavirus infection. Intervirology. 1990;31(2-4):109-15.

[12] Buck CB, Pastrana DV, Lowy DR, Schiller JT. Efficient intracellular assembly of papillomaviral vectors. Journal of virology. 2004 Jan;78(2):751-7.

[13] Roberts JN, Buck CB, Thompson CD, Kines R, Bernardo M, Choyke PL, Lowy DR, Schiller JT. Genital transmission of HPV in a mouse model is potentiated by nonoxynol-9 and inhibited by carrageenan. Nature medicine. 2007 Jul;13(7):857-61.

[14] Day PM, Kines RC, Thompson CD, Jagu S, Roden RB, Lowy DR, Schiller JT. In vivo mechanisms of vaccine-induced protection against HPV infection. Cell host \& microbe. 2010 Sep 16;8(3):260-70.

[15] Inglis S, Shaw A, Koenig S. Chapter 11: HPV vaccines: commercial research \& development. Vaccine. 2006 Aug 31;24 Suppl 3:S3/99-105.

[16] Schiller JT, Castellsague X, Villa LL, Hildesheim A. An update of prophylactic human papillomavirus L1 virus-like particle vaccine clinical trial results. Vaccine. 2008 Aug 19;26 Suppl 10:K53-61.

[17] Keam SJ, Harper DM. Human papillomavirus types 16 and 18 vaccine (recombinant, AS04 adjuvanted, adsorbed) [Cervarix]. Drugs. 2008;68(3):359-72. 
[18] Siddiqui MA, Perry CM. Human papillomavirus quadrivalent (types 6, 11, 16, 18) recombinant vaccine (Gardasil). Drugs. 2006;66(9):1263-71; discussion 72-3.

[19] GlaxoSmithKline Inc. Product Monograph : CERVARIX® Human Papillomavirus vaccine Types 16 and 18 (Recombinant, AS04 adjuvanted). 2012; Available from: http://www.gsk.ca/english/docs-pdf/product-monographs/Cervarix.pdf.

[20] MERCK Canada Inc. Product monograph: GARDASIL® [Quadrivalent Human Papillomavirus (Types 6, 11, 16, 18) Recombinant Vaccine]. 2011 [cited 2012 October]; Available from: http://www.merck.ca/assets/en/pdf/products/GARDASIL-PM_E.pdf.

[21] Munoz N, Manalastas R, Jr., Pitisuttithum P, Tresukosol D, Monsonego J, Ault K, Clavel C, Luna J, Myers E, Hood S, Bautista O, Bryan J, Taddeo FJ, Esser MT, Vuocolo S, Haupt RM, Barr E, Saah A. Safety, immunogenicity, and efficacy of quadrivalent human papillomavirus (types $6,11,16,18$ ) recombinant vaccine in women aged 24-45 years: a randomised, double-blind trial. Lancet. 2009 Jun 6;373(9679):1949-57.

[22] Descamps D, Hardt K, Spiessens B, Izurieta P, Verstraeten T, Breuer T, Dubin G. Safety of human papillomavirus (HPV)-16/18 AS04-adjuvanted vaccine for cervical cancer prevention: a pooled analysis of 11 clinical trials. Hum Vaccin. 2009 May;5(5): $332-40$.

[23] Einstein MH, Baron M, Levin MJ, Chatterjee A, Edwards RP, Zepp F, Carletti I, Dessy FJ, Trofa AF, Schuind A, Dubin G. Comparison of the immunogenicity and safety of Cervarix and Gardasil human papillomavirus (HPV) cervical cancer vaccines in healthy women aged 18-45 years. Human vaccines. 2009 Oct;5(10):705-19.

[24] Omer SB. Safety of quadrivalent human papillomavirus vaccine. J Intern Med. 2012 Feb;271(2):177-8.

[25] Wacholder S, Chen BE, Wilcox A, Macones G, Gonzalez P, Befano B, Hildesheim A, Rodriguez AC, Solomon D, Herrero R, Schiffman M. Risk of miscarriage with bivalent vaccine against human papillomavirus (HPV) types 16 and 18: pooled analysis of two randomised controlled trials. BMJ. 2010;340:c712.

[26] Forinash AB, Yancey AM, Pitlick JM, Myles TD. Safety of the HPV Bivalent and Quadrivalent Vaccines During Pregnancy (February). Ann Pharmacother. 2011 Feb 1.

[27] Lehtinen M, Nieminen P, Apter D, Namujju P, Natunen K, Rana M, Paavonen J. Immunogenicity, Efficacy, Effectiveness and Overall Impact of HPV Vaccines. In: Ridder FBaM, editor. HPV and Cervical Cancer: ; 2012. p. 257-72.

[28] Mariani L, Venuti A. HPV vaccine: an overview of immune response, clinical protection, and new approaches for the future. J Transl Med. 2010;8:105.

[29] Breitburd F, Kirnbauer R, Hubbert NL, Nonnenmacher B, Trindinhdesmarquet C, Orth G, Schiller JT, Lowy DR. Immunization with Virus-Like Particles from Cottontail Rabbit Papillomavirus (Crpv) Can Protect against Experimental Crpv Infection. Journal of Virology. 1995 Jun;69(6):3959-63. 
[30] Ghim S, Newsome J, Bell J, Sundberg JP, Schlegel R, Jenson AB. Spontaneously regressing oral papillomas induce systemic antibodies that neutralize canine oral papillomavirus. Exp Mol Pathol. 2000 Jun;68(3):147-51.

[31] Rotelli-Martins CM, Naud P, De Borba P, Teixeira JC, De Carvalho NS, Zahaf T, Sanchez N, Geeraerts B, Descamps D. Sustained immunogenicity and efficacy of the HPV-16/18 AS04-adjuvanted vaccine. Human vaccines \& Immunotherapeutics. 2012;8(3).

[32] Castellsague X, Munoz N, Pitisuttithum P, Ferris D, Monsonego J, Ault K, Luna J, Myers E, Mallary S, Bautista OM, Bryan J, Vuocolo S, Haupt RM, Saah A. End-ofstudy safety, immunogenicity, and efficacy of quadrivalent HPV (types 6, 11, 16, 18) recombinant vaccine in adult women 24-45 years of age. Br J Cancer. 2011 Jun 28;105(1):28-37.

[33] Harper DM, Franco EL, Wheeler C, Ferris DG, Jenkins D, Schuind A, Zahaf T, Innis B, Naud P, De Carvalho NS, Roteli-Martins CM, Teixeira J, Blatter MM, Korn AP, Quint W, Dubin G. Efficacy of a bivalent L1 virus-like particle vaccine in prevention of infection with human papillomavirus types 16 and 18 in young women: a randomised controlled trial. Lancet. 2004 Nov 13-19;364(9447):1757-65.

[34] Paavonen J, Naud P, Salmeron J, Wheeler CM, Chow SN, Apter D, Kitchener H, Castellsague X, Teixeira JC, Skinner SR, Hedrick J, Jaisamrarn U, Limson G, Garland S, Szarewski A, Romanowski B, Aoki FY, Schwarz TF, Poppe WA, Bosch FX, Jenkins D, Hardt K, Zahaf T, Descamps D, Struyf F, Lehtinen M, Dubin G. Efficacy of human papillomavirus (HPV)-16/18 AS04-adjuvanted vaccine against cervical infection and precancer caused by oncogenic HPV types (PATRICIA): final analysis of a doubleblind, randomised study in young women. Lancet. 2009 Jul 25;374(9686):301-14.

[35] Harper DM, Franco EL, Wheeler CM, Moscicki AB, Romanowski B, Roteli-Martins CM, Jenkins D, Schuind A, Costa Clemens SA, Dubin G. Sustained efficacy up to 4.5 years of a bivalent L1 virus-like particle vaccine against human papillomavirus types 16 and 18: follow-up from a randomised control trial. Lancet. 2006 Apr 15;367(9518): 1247-55.

[36] Harper DM. Impact of vaccination with Cervarix (trade mark) on subsequent HPV-16/18 infection and cervical disease in women 15-25 years of age. Gynecol Oncol. 2008 Sep;110(3 Suppl 1):S11-7.

[37] De Carvalho N, Teixeira J, Roteli-Martins CM, Naud P, De Borba P, Zahaf T, Sanchez N, Schuind A. Sustained efficacy and immunogenicity of the HPV-16/18 AS04-adjuvanted vaccine up to 7.3 years in young adult women. Vaccine. 2010 Aug 31;28(38): 6247-55.

[38] Roteli-Martins CM, Naud P, De Borba P, Teixeira JC, De Carvalho NS, Zahaf T, Sanchez N, Geeraerts B, Descamps D. Sustained immunogenicity and efficacy of the 
HPV-16/18 AS04-adjuvanted vaccine: up to 8.4 years of follow-up. Hum Vaccin Immunother. 2012 Mar;8(3):390-7.

[39] Quadrivalent vaccine against human papillomavirus to prevent high-grade cervical lesions. N Engl J Med. 2007 May 10;356(19):1915-27.

[40] Garland SM, Hernandez-Avila M, Wheeler CM, Perez G, Harper DM, Leodolter S, Tang GW, Ferris DG, Steben M, Bryan J, Taddeo FJ, Railkar R, Esser MT, Sings HL, Nelson M, Boslego J, Sattler C, Barr E, Koutsky LA. Quadrivalent vaccine against human papillomavirus to prevent anogenital diseases. N Engl J Med. 2007 May 10;356(19):1928-43.

[41] Villa LL, Costa RL, Petta CA, Andrade RP, Paavonen J, Iversen OE, Olsson SE, Hoye J, Steinwall M, Riis-Johannessen G, Andersson-Ellstrom A, Elfgren K, Krogh G, Lehtinen M, Malm C, Tamms GM, Giacoletti K, Lupinacci L, Railkar R, Taddeo FJ, Bryan J, Esser MT, Sings HL, Saah AJ, Barr E. High sustained efficacy of a prophylactic quadrivalent human papillomavirus types 6/11/16/18 L1 virus-like particle vaccine through 5 years of follow-up. Br J Cancer. 2006 Dec 4;95(11):1459-66.

[42] Harper DM, Franco EL, Wheeler C, Ferris DG, Jenkins D, Schuind A, Zahaf T, Innis B, Naud P, De Carvalho NS, Roteli-Martins CM, Teixeira J, Blatter MM, Korn AP, Quint W, Dubin G. Efficacy of a bivalent L1 virus-like particle vaccine in prevention of infection with human papillomavirus types 16 and 18 in young women: a randomised controlled trial. The Lancet. 2004;364(9447):1757-65.

[43] Villa LL, Costa RLR, Petta CA, Andrade RP, Ault KA, Giuliano AR, Wheeler CM, Koutsky LA, Malm C, Lehtinen M, Skjeldestad FE, Olsson S-E, Steinwall M, Brown DR, Kurman RJ, Ronnett BM, Stoler MH, Ferenczy A, Harper DM, Tamms GM, Yu J, Lupinacci L, Railkar R, Taddeo FJ, Jansen KU, Esser MT, Sings HL, Saah AJ, Barr E. Prophylactic quadrivalent human papillomavirus (types 6, 11, 16, and 18) L1 viruslike particle vaccine in young women: a randomised double-blind placebo-controlled multicentre phase II efficacy trial. The Lancet Oncology. 2005;6(5):271-8.

[44] Garland SM, Hernandez-Avila M, Wheeler CM, Perez G, Harper DM, Leodolter S, Tang GWK, Ferris DG, Steben M, Bryan J, Taddeo FJ, Railkar R, Esser MT, Sings HL, Nelson M, Boslego J, Sattler C, Barr E, Koutsky LA. Quadrivalent vaccine against human papillomavirus to prevent anogenital diseases. New England Journal of Medicine. 2007 May 10;356(19):1928-43.

[45] Villa LL, Perez G, Kjaer SK, Paavonen J, Lehtinen M, Munoz N, Sigurdsson K, Hernandez-Avila M, Skjeldestad FE, Thoresen S, Garcia P, Majewski S, Dillner J, Olsson SE, Tay EH, Bosch FX, Ault KA, et al.. Quadrivalent vaccine against human papillomavirus to prevent high-grade cervical lesions. New England Journal of Medicine. 2007 May 10;356(19):1915-27.

[46] Paavonen J, Jenkins D, Bosch FX, Naud P, Salmeron J, Wheeler CM, Chow SN, Apter DL, Kitchener HC, Castellsague X, de Carvalho NS, Skinner SR, Harper DM, Hedrick JA, Jaisamrarn U, Limson GAM, Dionne M, Quint W, Spiessens B, Peeters P, Struyf F, 
Wieting SL, Lehtinen MO, Dubin G. Efficacy of a prophylactic adjuvanted bivalent L1 virus-like-particle vaccine against infection with human papillomavirus types 16 and 18 in young women: an interim analysis of a phase III double-blind, randomised controlled trial. Lancet. 2007 Jun 30;369(9580):2161-70.

[47] Paavonen J, Jenkins D, Bosch FX, Naud P, Salmeron J, Wheeler CM, Chow SN, Apter DL, Kitchener HC, Castellsague X, de Carvalho NS, Skinner SR, Harper DM, Hedrick JA, Jaisamrarn U, Limson GA, Dionne M, Quint W, Spiessens B, Peeters P, Struyf F, Wieting SL, Lehtinen MO, Dubin G. Efficacy of a prophylactic adjuvanted bivalent L1 virus-like-particle vaccine against infection with human papillomavirus types 16 and 18 in young women: an interim analysis of a phase III double-blind, randomised controlled trial. Lancet. 2007 Jun 30;369(9580):2161-70.

[48] Villa LL, Costa RLR, Petta CA, Andrade RP, Paavonen J, Iversen OE, Olsson SE, Hoye J, Steinwall M, Riis-Johannessen G, Andersson-Ellstrom A, Elfgren K, von Krogh G, Lehtinen M, Malm C, Tamms GM, Giacoletti K, Lupinacci L, Railkar R, Taddeo FJ, Bryan J, Esser MT, Sings HL, Saah AJ, Barr E. High sustained efficacy of a prophylactic quadrivalent human papillomavirus types 6/11/16/18 L1 virus-like particle vaccine through 5 years of follow-up. British Journal of Cancer. 2006 Dec 4;95(11):1459-66.

[49] Dillner J, Kjaer SK, Wheeler CM, Sigurdsson K, Iversen OE, Hernandez-Avila M, Perez G, Brown DR, Koutsky LA, Tay EH, Garcia P, Ault KA, Garland SM, Leodolter S, Olsson SE, Tang GWK, Ferris DG, Paavonen J, Lehtinen M, Steben M, Bosch FX, Joura EA, Majewski S, Munoz N, Myers ER, Villa LL, Taddeo FJ, Roberts C, Tadesse A, Bryan JT, Maansson R, Lu SA, Vuocolo S, Hesley TM, Barr E, Haupt R, Grp FIIS. Four year efficacy of prophylactic human papillomavirus quadrivalent vaccine against low grade cervical, vulvar, and vaginal intraepithelial neoplasia and anogenital warts: randomised controlled trial. British Medical Journal. 2010 Jul 20;341.

[50] FUTUREII. Quadrivalent vaccine against human papillomavirus to prevent highgrade cervical lesions. N Engl J Med. 2007 May 10;356(19):1915-27.

[51] Kreimer AR, González P, Katki HA, Porras C, Schiffman M, Rodriguez AC, Solomon D, Jiménez S, Schiller JT, Lowy DR, van Doorn L-J, Struijk L, Quint W, Chen S, Wacholder S, Hildesheim A, Herrero R. Efficacy of a bivalent HPV 16/18 vaccine against anal HPV 16/18 infection among young women: a nested analysis within the Costa Rica Vaccine Trial. The Lancet Oncology. 2011;12(9):862-70.

[52] Wheeler CM, Castellsague X, Garland SM, Szarewski A, Paavonen J, Naud P, Salmeron J, Chow SN, Apter D, Kitchener H, Teixeira JC, Skinner SR, Jaisamrarn U, Limson G, Romanowski B, Aoki FY, Schwarz TF, Poppe WA, Bosch FX, Harper DM, Huh W, Hardt K, Zahaf T, Descamps D, Struyf F, Dubin G, Lehtinen M, Group HPS. Crossprotective efficacy of HPV-16/18 AS04-adjuvanted vaccine against cervical infection and precancer caused by non-vaccine oncogenic HPV types: 4-year end-of-study 
analysis of the randomised, double-blind PATRICIA trial. Lancet Oncol. 2012 Jan; 13(1):100-10.

[53] Paavonen J. Efficacy of human papillomavirus (HPV)-16/18AS04-adjuvanted vaccine against cervical infection and precancer caused by oncogenic HPV types (PATRICIA): final analysis of a double-blind, randomised study in young women (vol 374, pg 301, 2009). Lancet. 2010 Sep-Oct;376(9746):1054-.

[54] Malagón T, Drolet M, Boily M-C, Franco EL, Jit M, Brisson J, Brisson M. Cross-protective efficacy of two human papillomavirus vaccines: a systematic review and metaanalysis. The Lancet Infectious Diseases. 2012.

[55] Einstein MH, Baron M, Levin MJ, Chatterjee A, Fox B, Scholar S, Rosen J, Chakhtoura N, Lebacq M, van der Most R, Moris P, Giannini SL, Schuind A, Datta SK, Descamps $\mathrm{D}$, Group HPVS. Comparison of the immunogenicity of the human papillomavirus (HPV)-16/18 vaccine and the HPV-6/11/16/18 vaccine for oncogenic non-vaccine types HPV-31 and HPV-45 in healthy women aged 18-45 years. Hum Vaccin. 2011 Dec;7(12):1359-73.

[56] Hildesheim A, Herrero R. Human papillomavirus vaccine should be given before sexual debut for maximum benefit. The Journal of infectious diseases. 2007 Nov 15;196(10):1431-2.

[57] CDC. Quadrivalent Human Papillomavirus Vaccine. 2007 [cited 2012 October]; Available from: http://www.cdc.gov/mmwr/preview/mmwrhtml/mm5920a4.htm.

[58] CDC. FDA Licensure of Quadrivalent Human Papillomavirus Vaccine (HPV4, Gardasil) for Use in Males and Guidance from the Advisory Committee on Immunization Practices (ACIP). 2010 [cited 2012 October]; Available from: http://www.cdc.gov/ $\mathrm{mmwr} /$ preview/mmwrhtml/mm5920a5.htm.

[59] Petaja T, Pedersen C, Poder A, Strauss G, Catteau G, Thomas F, Lehtinen M, Descamps D. Long-term persistence of systemic and mucosal immune response to HPV-16/18 AS04-adjuvanted vaccine in preteen/adolescent girls and young women. Int J Cancer. 2011 Nov 1;129(9):2147-57.

[60] Woodman CB, Collins SI, Young LS. The natural history of cervical HPV infection: unresolved issues. Nat Rev Cancer. 2007 Jan;7(1):11-22.

[61] de Sanjosé S, Diaz M, Castellsagué X, Clifford G, Bruni L, Muñoz N, Bosch FX. Worldwide prevalence and genotype distribution of cervical human papillomavirus DNA in women with normal cytology: a meta-analysis. The Lancet Infectious Diseases. 2007;7(7):453-9.

[62] Schwarz TF, Spaczynski M, Schneider A, Wysocki J, Galaj A, Schulze K, Poncelet SM, Catteau G, Thomas F, Descamps D. Persistence of immune response to HPV-16/18 AS04-adjuvanted cervical cancer vaccine in women aged 15-55 years. Hum Vaccin. 2011 Sep;7(9):958-65. 
[63] Joura EA, Garland SM, Paavonen J, Ferris DG, Perez G, Ault KA, Huh WK, Sings HL, James MK, Haupt RM. Effect of the human papillomavirus (HPV) quadrivalent vaccine in a subgroup of women with cervical and vulvar disease: retrospective pooled analysis of trial data. Bmj. 2012;344(mar27 3):e1401-e.

[64] Giuliano AR, Lu B, Nielson CM, Flores R, Papenfuss MR, Lee JH, Abrahamsen M, Harris RB. Age-specific prevalence, incidence, and duration of human papillomavirus infections in a cohort of 290 US men. J Infect Dis. 2008 Sep 15;198(6):827-35.

[65] Garnock-Jones KP, Giuliano AR. Quadrivalent human papillomavirus (HPV) types 6, 11, 16, 18 vaccine: for the prevention of genital warts in males. Drugs. 2011 Mar 26;71(5):591-602.

[66] Hillman RJ, Giuliano AR, Palefsky JM, Goldstone S, Moreira ED, Jr., Vardas E, Aranda C, Jessen H, Ferris DG, Coutlee F, Marshall JB, Vuocolo S, Haupt RM, Guris D, Garner EI. Immunogenicity of the quadrivalent human papillomavirus (type 6/11/16/18) vaccine in males 16 to 26 years old. Clin Vaccine Immunol. 2012 Feb;19(2): 261-7.

[67] Kim JJ, Goldie SJ. Cost effectiveness analysis of including boys in a human papillomavirus vaccination programme in the United States. Bmj. 2009;339(oct08 2):b3884-b.

[68] Palefsky JM, Giuliano AR, Goldstone S, Moreira ED, Aranda C, Jessen H, Hillman R, Ferris D, Coutlee F, Stoler MH, Marshall JB, Radley D, Vuocolo S, Haupt RM, Guris D, Garner EIO. HPV Vaccine against Anal HPV Infection and Anal Intraepithelial Neoplasia. New Engl J Med. 2011 Oct 27;365(17):1576-85.

[69] Levin MJ, Moscicki AB, Song LY, Fenton T, Meyer WA, 3rd, Read JS, Handelsman EL, Nowak B, Sattler CA, Saah A, Radley DR, Esser MT, Weinberg A, Team IPP. Safety and immunogenicity of a quadrivalent human papillomavirus (types 6, 11, 16, and 18) vaccine in HIV-infected children 7 to 12 years old. J Acquir Immune Defic Syndr. 2010 Oct;55(2):197-204.

[70] Jochmus I, Schäfer K, Faath S, Müller M, Gissmann L. Chimeric virus-like particles of the human papillomavirus type 16 (HPV 16) as a prophylactic and therapeutic vaccine. Archives of medical research. 1999 Jul-Aug;30(4):269-74.

[71] Schäfer K, Müller M, Faath S, Henn A, Osen W, Zentgraf H, Benner A, Gissmann L, Jochmus I. Immune response to human papillomavirus 16 L1E7 chimeric virus-like particles: induction of cytotoxic $\mathrm{T}$ cells and specific tumor protection. International journal of cancer Journal international du cancer. 1999 Jun 11;81(6):881-8.

[72] Nieland JD, Da Silva DM, Velders MP, de Visser KE, Schiller JT, Müller M, Kast WM. Chimeric papillomavirus virus-like particles induce a murine self-antigen-specific protective and therapeutic antitumor immune response. Journal of cellular biochemistry. 1999 May 1;73(2):145-52. 
[73] Rudolf MP, Nieland JD, DaSilva DM, Velders MP, Müller M, Greenstone HL, Schiller JT, Kast WM. Induction of HPV16 capsid protein-specific human T cell responses by virus-like particles. Biological chemistry. 1999 Mar;380(3):335-40.

[74] Kreimer AR, Rodriguez AC, Hildesheim A, Herrero R, Porras C, Schiffman M, Gonzalez P, Solomon D, Jimenez S, Schiller JT, Lowy DR, Quint W, Sherman ME, Schussler J, Wacholder S. Proof-of-principle evaluation of the efficacy of fewer than three doses of a bivalent HPV16/18 vaccine. Journal of the National Cancer Institute. 2011 Oct 5;103(19):1444-51.

[75] CDC. Morbidity and Mortality Weekly Report: Progress Toward Implementation of Human Papillomavirus Vaccination - The Americas. http://wwwcdcgov/mmwr/ preview/mmwrhtml/mm6040a2htm. 2011;60(40):1382-4.

[76] Müller M, Zhou J, Reed TD, RittMüller C, Burger A, Gabelsberger J, Braspenning J, Gissmann L. Chimeric papillomavirus-like particles. Virology. 1997 Jul 21;234(1): 93-111.

[77] Biemelt S, Sonnewald U, Galmbacher P, Willmitzer L, Müller M. Production of human papillomavirus type 16 virus-like particles in transgenic plants. J Virol. 2003 Sep;77(17):9211-20.

[78] Schädlich L, Senger T, Gerlach B, Mucke N, Klein C, Bravo IG, Müller M, Gissmann L. Analysis of modified human papillomavirus type 16 L1 capsomeres: the ability to assemble into larger particles correlates with higher immunogenicity. J Virol. 2009 Aug;83(15):7690-705.

[79] Schmitt M, Fiedler V, Müller M. Prevalence of BPV genotypes in a German cowshed determined by a novel multiplex BPV genotyping assay. J Virol Methods. 2010 Dec; 170(1-2):67-72.

[80] Cho HJ, Han SE, Im S, Lee Y, Kim YB, Chun T, Oh YK. Maltosylated polyethylenimine-based triple nanocomplexes of human papillomavirus 16L1 protein and DNA as a vaccine co-delivery system. Biomaterials. 2011 Jul;32(20):4621-9.

[81] Gupta SK, Singh A, Srivastava M, Akhoon BA. In silico DNA vaccine designing against human papillomavirus (HPV) causing cervical cancer. Vaccine. 2009 Dec 10;28(1):120-31.

[82] Lee HJ, Park N, Cho HJ, Yoon JK, Van ND, Oh YK, Kim YB. Development of a novel viral DNA vaccine against human papillomavirus: AcHERV-HP16L1. Vaccine. 2010 Feb 10;28(6):1613-9.

[83] Maeda H, Kubo K, Sugita Y, Miyamoto Y, Komatsu S, Takeuchi S, Umebayashi T, Morikawa S, Kawanishi K, Kameyama Y. DNA vaccine against hamster oral papillomavirus-associated oral cancer. J Int Med Res. 2005 Nov-Dec;33(6):647-53. 
[84] Pokorna D, Rubio I, Müller M. DNA-vaccination via tattooing induces stronger humoral and cellular immune responses than intramuscular delivery supported by molecular adjuvants. Genet Vaccines Ther. 2008;6:4.

[85] Hu J, Cladel NM, Budgeon LR, Reed CA, Pickel MD, Christensen ND. Protective cellmediated immunity by DNA vaccination against Papillomavirus L1 capsid protein in the Cottontail Rabbit Papillomavirus model. Viral Immunol. 2006 Summer;19(3): 492-507.

[86] Zheng J, Si L, Song J, Sun X, Yu J, Wang Y. Enhanced immune response to DNAbased HPV16L1 vaccination by costimulatory molecule B7-2. Antiviral Res. 2003 Jun; 59(1):61-5.

[87] Moore RA, Nicholls PK, Santos EB, Gough GW, Stanley MA. Absence of canine oral papillomavirus DNA following prophylactic L1 particle-mediated immunotherapeutic delivery vaccination. J Gen Virol. 2002 Sep;83(Pt 9):2299-301.

[88] Stanley MA, Moore RA, Nicholls PK, Santos EB, Thomsen L, Parry N, Walcott S, Gough G. Intra-epithelial vaccination with COPV L1 DNA by particle-mediated DNA delivery protects against mucosal challenge with infectious COPV in beagle dogs. Vaccine. 2001 Apr 6;19(20-22):2783-92.

[89] Matsumoto K, Kawana K, Yoshikawa H, Taketani Y, Yoshiike K, Kanda T. DNA vaccination of mice with plasmid expressing human papillomavirus 6 major capsid protein L1 elicits type-specific antibodies neutralizing pseudovirions constructed in vitro. J Med Virol. 2000 Feb;60(2):200-4.

[90] Schreckenberger C, Sethupathi P, Kanjanahaluethai A, Müller M, Zhou J, Gissmann L, Qiao L. Induction of an HPV 6bL1-specific mucosal IgA response by DNA immunization. Vaccine. 2000 Sep 15;19(2-3):227-33.

[91] Leder C, Kleinschmidt JA, Wiethe C, Müller M. Enhancement of capsid gene expression: preparing the human papillomavirus type 16 major structural gene L1 for DNA vaccination purposes. J Virol. 2001 Oct;75(19):9201-9.

[92] Bins AD, Jorritsma A, Wolkers MC, Hung CF, Wu TC, Schumacher TN, Haanen JB. A rapid and potent DNA vaccination strategy defined by in vivo monitoring of antigen expression. Nat Med. 2005 Aug;11(8):899-904.

[93] Gopee NV, Cui Y, Olson G, Warbritton AR, Miller BJ, Couch LH, Wamer WG, Howard PC. Response of mouse skin to tattooing: use of SKH-1 mice as a surrogate model for human tattooing. Toxicol Appl Pharmacol. 2005 Dec 1;209(2):145-58.

[94] Gasparic M, Rubio I, Thönes N, Gissmann L, Müller M. Prophylactic DNA immunization against multiple papillomavirus types. Vaccine. 2007 Jun 6;25(23):4540-53.

[95] Lin Z, Yemelyanova AV, Gambhira R, Jagu S, Meyers C, Kirnbauer R, Ronnett BM, Gravitt PE, Roden RB. Expression pattern and subcellular localization of human pap- 
illomavirus minor capsid protein L2. The American journal of pathology. 2009 Jan; 174(1):136-43.

[96] Reuter JD, Vivas-Gonzalez BE, Gomez D, Wilson JH, Brandsma JL, Greenstone HL, Rose JK, Roberts A. Intranasal vaccination with a recombinant vesicular stomatitis virus expressing cottontail rabbit papillomavirus L1 protein provides complete protection against papillomavirus-induced disease. Journal of virology. 2002 Sep;76(17): 8900-9.

[97] Roberts A, Reuter JD, Wilson JH, Baldwin S, Rose JK. Complete protection from papillomavirus challenge after a single vaccination with a vesicular stomatitis virus vector expressing high levels of L1 protein. Journal of virology. 2004 Mar;78(6):3196-9.

[98] Berg M, Difatta J, Hoiczyk E, Schlegel R, Ketner G. Viable adenovirus vaccine prototypes: high-level production of a papillomavirus capsid antigen from the major late transcriptional unit. Proc Natl Acad Sci U S A. 2005 Mar 22;102(12):4590-5.

[99] Lin YL, Borenstein LA, Selvakumar R, Ahmed R, Wettstein FO. Effective vaccination against papilloma development by immunization with L1 or L2 structural protein of cottontail rabbit papillomavirus. Virology. 1992 Apr;187(2):612-9.

[100] Berg M, Gambhira R, Siracusa M, Hoiczyk E, Roden R, Ketner G. HPV16 L1 capsid protein expressed from viable adenovirus recombinants elicits neutralizing antibody in mice. Vaccine. 2007 Apr 30;25(17):3501-10.

[101] Nieto K, Stahl-Hennig C, Leuchs B, Müller M, Gissmann L, Kleinschmidt JA. Intranasal Vaccination with AAV5 and 9 Vectors Against Human Papillomavirus Type 16 in Rhesus Macaques. Hum Gene Ther. 2012 Jul;23(7):733-41.

[102] Nieto K, Kern A, Leuchs B, Gissmann L, Müller M, Kleinschmidt JA. Combined prophylactic and therapeutic intranasal vaccination against human papillomavirus type-16 using different adeno-associated virus serotype vectors. Antivir Ther. 2009;14(8):1125-37.

[103] Kuck D, Lau T, Leuchs B, Kern A, Müller M, Gissmann L, Kleinschmidt JA. Intranasal vaccination with recombinant adeno-associated virus type 5 against human papillomavirus type 16 L1. J Virol. 2006 Mar;80(6):2621-30.

[104] Kuck D, Leder C, Kern A, Müller M, Piuko K, Gissmann L, Kleinschmidt JA. Efficiency of HPV 16 L1/E7 DNA immunization: influence of cellular localization and capsid assembly. Vaccine. 2006 Apr 5;24(15):2952-65.

[105] Liu DW, Chang JL, Tsao YP, Huang CW, Kuo SW, Chen SL. Co-vaccination with adeno-associated virus vectors encoding human papillomavirus 16 L1 proteins and adenovirus encoding murine GM-CSF can elicit strong and prolonged neutralizing antibody. International journal of cancer Journal international du cancer. 2005 Jan 1;113(1):93-100.

[106] Echchannaoui H, Bianchi M, Baud D, Bobst M, Stehle JC, Nardelli-Haefliger D. Intravaginal immunization of mice with recombinant Salmonella enterica serovar Typhi- 
murium expressing human papillomavirus type 16 antigens as a potential route of vaccination against cervical cancer. Infect Immun. 2008 May;76(5):1940-51.

[107] Baud D, Ponci F, Bobst M, De Grandi P, Nardelli-Haefliger D. Improved efficiency of a Salmonella-based vaccine against human papillomavirus type 16 virus-like particles achieved by using a codon-optimized version of L1. J Virol. 2004 Dec;78(23): 12901-9.

[108] Revaz V, Benyacoub J, Kast WM, Schiller JT, De Grandi P, Nardelli-Haefliger D. Mucosal vaccination with a recombinant Salmonella typhimurium expressing human papillomavirus type 16 (HPV16) L1 virus-like particles (VLPs) or HPV16 VLPs purified from insect cells inhibits the growth of HPV16-expressing tumor cells in mice. Virology. 2001 Jan 5;279(1):354-60.

[109] Nardelli-Haefliger D, Roden RB, Benyacoub J, Sahli R, Kraehenbuhl JP, Schiller JT, Lachat P, Potts A, De Grandi P. Human papillomavirus type 16 virus-like particles expressed in attenuated Salmonella typhimurium elicit mucosal and systemic neutralizing antibodies in mice. Infect Immun. 1997 Aug;65(8):3328-36.

[110] Govan VA, Christensen ND, Berkower C, Jacobs WR, Jr., Williamson AL. Immunisation with recombinant BCG expressing the cottontail rabbit papillomavirus (CRPV) L1 gene provides protection from CRPV challenge. Vaccine. 2006 Mar 15;24(12): 2087-93.

[111] Jabbar IA, Fernando GJ, Saunders N, Aldovini A, Young R, Malcolm K, Frazer IH. Immune responses induced by BCG recombinant for human papillomavirus L1 and E7 proteins. Vaccine. 2000 May 8;18(22):2444-53.

[112] Chen XS, Casini G, Harrison SC, Garcea RL. Papillomavirus capsid protein expression in Escherichia coli: purification and assembly of HPV11 and HPV16 L1. J Mol Biol. 2001 Mar 16;307(1):173-82.

[113] Thönes N, Herreiner A, Schädlich L, Piuko K, Müller M. A direct comparison of human papillomavirus type $16 \mathrm{~L} 1$ particles reveals a lower immunogenicity of capsomeres than viruslike particles with respect to the induced antibody response. J Virol. 2008 Jun;82(11):5472-85.

[114] Schädlich L, Senger T, Gerlach B, Mucke N, Klein C, Bravo IG, Müller M, Gissmann L. Analysis of modified human papillomavirus type 16 L1 capsomeres: the ability to assemble into larger particles correlates with higher immunogenicity. J Virol. 2009 Aug;83(15):7690-705.

[115] Stahl-Hennig C, Eisenblatter M, Jasny E, Rzehak T, Tenner-Racz K, Trumpfheller C, Salazar AM, Uberla K, Nieto K, Kleinschmidt J, Schulte R, Gissmann L, Müller M, Sacher A, Racz P, Steinman RM, Uguccioni M, Ignatius R. Synthetic double-stranded RNAs are adjuvants for the induction of $\mathrm{T}$ helper 1 and humoral immune responses to human papillomavirus in rhesus macaques. PLoS Pathog. 2009 Apr;5(4):e1000373. 
[116] Mason HS, Lam DM, Arntzen CJ. Expression of hepatitis B surface antigen in transgenic plants. Proc Natl Acad Sci U S A. 1992 Dec 15;89(24):11745-9.

[117] Thanavala Y, Yang YF, Lyons P, Mason HS, Arntzen C. Immunogenicity of transgenic plant-derived hepatitis B surface antigen. Proc Natl Acad Sci U S A. 1995 Apr 11;92(8):3358-61.

[118] Matic S, Masenga V, Poli A, Rinaldi R, Milne RG, Vecchiati M, Noris E. Comparative analysis of recombinant Human Papillomavirus $8 \mathrm{~L} 1$ production in plants by a variety of expression systems and purification methods. Plant Biotechnol J. 2012 May; 10(4):410-21.

[119] Matic S, Rinaldi R, Masenga V, Noris E. Efficient production of chimeric human papillomavirus 16 L1 protein bearing the M2e influenza epitope in Nicotiana benthamiana plants. BMC Biotechnol. 2011;11:106.

[120] Waheed MT, Thönes N, Müller M, Hassan SW, Gottschamel J, Lossl E, Kaul HP, Lossl AG. Plastid expression of a double-pentameric vaccine candidate containing human papillomavirus-16 L1 antigen fused with LTB as adjuvant: transplastomic plants show pleiotropic phenotypes. Plant Biotechnol J. 2011 Aug;9(6):651-60.

[121] Paz De la Rosa G, Monroy-Garcia A, Mora-Garcia Mde L, Pena CG, Hernandez-Montes J, Weiss-Steider B, Gomez-Lim MA. An HPV 16 L1-based chimeric human papilloma virus-like particles containing a string of epitopes produced in plants is able to elicit humoral and cytotoxic T-cell activity in mice. Virol J. 2009;6:2.

[122] Lenzi P, Scotti N, Alagna F, Tornesello ML, Pompa A, Vitale A, De Stradis A, Monti L, Grillo S, Buonaguro FM, Maliga P, Cardi T. Translational fusion of chloroplast-expressed human papillomavirus type 16 L1 capsid protein enhances antigen accumulation in transplastomic tobacco. Transgenic Res. 2008 Dec;17(6):1091-102.

[123] Fernandez-San Millan A, Ortigosa SM, Hervas-Stubbs S, Corral-Martinez P, Segui-Simarro JM, Gaetan J, Coursaget P, Veramendi J. Human papillomavirus L1 protein expressed in tobacco chloroplasts self-assembles into virus-like particles that are highly immunogenic. Plant Biotechnol J. 2008 Jun;6(5):427-41.

[124] Kohl TO, Hitzeroth, II, Christensen ND, Rybicki EP. Expression of HPV-11 L1 protein in transgenic Arabidopsis thaliana and Nicotiana tabacum. BMC Biotechnol. 2007;7:56.

[125] Maclean J, Koekemoer M, Olivier AJ, Stewart D, Hitzeroth, II, Rademacher T, Fischer R, Williamson AL, Rybicki EP. Optimization of human papillomavirus type 16 (HPV-16) L1 expression in plants: comparison of the suitability of different HPV-16 L1 gene variants and different cell-compartment localization. J Gen Virol. 2007 May; 88(Pt 5):1460-9.

[126] Kohl T, Hitzeroth, II, Stewart D, Varsani A, Govan VA, Christensen ND, Williamson AL, Rybicki EP. Plant-produced cottontail rabbit papillomavirus L1 protein protects 
against tumor challenge: a proof-of-concept study. Clin Vaccine Immunol. 2006 Aug; 13(8):845-53.

[127] Varsani A, Williamson AL, Stewart D, Rybicki EP. Transient expression of Human papillomavirus type $16 \mathrm{~L} 1$ protein in Nicotiana benthamiana using an infectious tobamovirus vector. Virus Res. 2006 Sep;120(1-2):91-6.

[128] Liu HL, Li WS, Lei T, Zheng J, Zhang Z, Yan XF, Wang ZZ, Wang YL, Si LS. Expression of human papillomavirus type $16 \mathrm{~L} 1$ protein in transgenic tobacco plants. Acta Biochim Biophys Sin (Shanghai). 2005 Mar;37(3):153-8.

[129] Campo MS, O'Neil BW, Grindlay GJ, Curtis F, Knowles G, Chandrachud L. A peptide encoding a B-cell epitope from the N-terminus of the capsid protein L2 of bovine papillomavirus-4 prevents disease. Virology. 1997 Aug 4;234(2):261-6.

[130] Roden RB, Yutzy WHt, Fallon R, Inglis S, Lowy DR, Schiller JT. Minor capsid protein of human genital papillomaviruses contains subdominant, cross-neutralizing epitopes. Virology. 2000 May 10;270(2):254-7.

[131] Pastrana DV, Gambhira R, Buck CB, Pang YY, Thompson CD, Culp TD, Christensen ND, Lowy DR, Schiller JT, Roden RB. Cross-neutralization of cutaneous and mucosal Papillomavirus types with anti-sera to the amino terminus of L2. Virology. $2005 \mathrm{Jul}$ 5;337(2):365-72.

[132] Gambhira R, Karanam B, Jagu S, Roberts JN, Buck CB, Bossis I, Alphs H, Culp T, Christensen ND, Roden RB. A protective and broadly cross-neutralizing epitope of human papillomavirus L2. Journal of virology. 2007 Dec;81(24):13927-31.

[133] Gambhira R, Jagu S, Karanam B, Gravitt PE, Culp TD, Christensen ND, Roden RB. Protection of rabbits against challenge with rabbit papillomaviruses by immunization with the $\mathrm{N}$ terminus of human papillomavirus type 16 minor capsid antigen L2. Journal of virology. 2007 Nov;81(21):11585-92.

[134] Davidson EJ, Faulkner RL, Sehr P, Pawlita M, Smyth LJ, Burt DJ, Tomlinson AE, Hickling J, Kitchener HC, Stern PL. Effect of TA-CIN (HPV 16 L2E6E7) booster immunisation in vulval intraepithelial neoplasia patients previously vaccinated with TA-HPV (vaccinia virus encoding HPV 16/18 E6E7). Vaccine. 2004 Jul 29;22(21-22): 2722-9.

[135] Kondo K, Ishii Y, Ochi H, Matsumoto T, Yoshikawa H, Kanda T. Neutralization of HPV16, 18, 31, and 58 pseudovirions with antisera induced by immunizing rabbits with synthetic peptides representing segments of the HPV16 minor capsid protein L2 surface region. Virology. 2007 Feb 20;358(2):266-72.

[136] Rubio I, Seitz H, Canali E, Sehr P, Bolchi A, Tommasino M, Ottonello S, Müller M. The N-terminal region of the human papillomavirus L2 protein contains overlapping binding sites for neutralizing, cross-neutralizing and non-neutralizing antibodies. Virology. 2011 Jan 20;409(2):348-59. 
[137] Rubio I, Bolchi A, Moretto N, Canali E, Gissmann L, Tommasino M, Müller M, Ottonello S. Potent anti-HPV immune responses induced by tandem repeats of the HPV16 L2 (20 -- 38) peptide displayed on bacterial thioredoxin. Vaccine. 2009 Mar 18;27(13):1949-56.

[138] Gambhira R, Karanam B, Jagu S, Roberts JN, Buck CB, Bossis I, Alphs H, Culp T, Christensen ND, Roden RB. A protective and broadly cross-neutralizing epitope of human papillomavirus L2. J Virol. 2007 Dec;81(24):13927-31.

[139] Alphs HH, Gambhira R, Karanam B, Roberts JN, Jagu S, Schiller JT, Zeng W, Jackson DC, Roden RB. Protection against heterologous human papillomavirus challenge by a synthetic lipopeptide vaccine containing a broadly cross-neutralizing epitope of L2. Proc Natl Acad Sci U S A. 2008 Apr 15;105(15):5850-5.

[140] Tumban E, Peabody J, Peabody DS, Chackerian B. A pan-HPV vaccine based on bacteriophage PP7 VLPs displaying broadly cross-neutralizing epitopes from the HPV minor capsid protein, L2. PloS one. 2011;6(8):e23310.

[141] Caldeira Jdo C, Medford A, Kines RC, Lino CA, Schiller JT, Chackerian B, Peabody DS. Immunogenic display of diverse peptides, including a broadly cross-type neutralizing human papillomavirus L2 epitope, on virus-like particles of the RNA bacteriophage PP7. Vaccine. 2010 Jun 17;28(27):4384-93.

[142] Schellenbacher C, Roden R, Kirnbauer R. Chimeric L1-L2 virus-like particles as potential broad-spectrum human papillomavirus vaccines. J Virol. 2009 Oct;83(19): 10085-95.

[143] Moretto N, Bolchi A, Rivetti C, Imbimbo BP, Villetti G, Pietrini V, Polonelli L, Del Signore S, Smith KM, Ferrante RJ, Ottonello S. Conformation-sensitive antibodies against alzheimer amyloid-beta by immunization with a thioredoxin-constrained Bcell epitope peptide. The Journal of biological chemistry. 2007 Apr 13;282(15): 11436-45.

[144] Day PM, Pang YY, Kines RC, Thompson CD, Lowy DR, Schiller JT. A human papillomavirus (HPV) in vitro neutralization assay that recapitulates the in vitro process of infection provides a sensitive measure of HPV L2 infection-inhibiting antibodies. Clinical and vaccine immunology : CVI. 2012 Jul;19(7):1075-82.

[145] Roberts JN, Kines RC, Katki HA, Lowy DR, Schiller JT. Effect of Pap smear collection and carrageenan on cervicovaginal human papillomavirus-16 infection in a rhesus macaque model. Journal of the National Cancer Institute. 2011 May 4;103(9):737-43.

[146] Repp KK, Nielson CM, Fu R, Schäfer S, Lazcano-Ponce E, Salmeron J, Quiterio M, Villa LL, Giuliano AR, study HIM. Male human papillomavirus prevalence and association with condom use in Brazil, Mexico, and the United States. J Infect Dis. 2012 Apr 15;205(8):1287-93. 
[147] Siegfried N, Müller M, Deeks JJ, Volmink J. Male circumcision for prevention of heterosexual acquisition of HIV in men. Cochrane Database Syst Rev. 2009(2):CD003362.

[148] Van Wagoner NJ, Geisler WM, Sizemore JM, Jr., Whitley R, Hook EW, 3rd. Herpes simplex virus in african american heterosexual males: the roles of age and male circumcision. Sex Transm Dis. 2010 Apr;37(4):217-22.

[149] Auvert B, Sobngwi-Tambekou J, Cutler E, Nieuwoudt M, Lissouba P, Puren A, Taljaard D. Effect of Male Circumcision on the Prevalence of High-Risk Human Papillomavirus in Young Men: Results of a Randomized Controlled Trial Conducted in Orange Farm, South Africa. Journal of Infectious Diseases. 2009 Jan 1;199(1):14-9.

[150] Gray RH, Serwadda D, Kong X, Makumbi F, Kigozi G, Gravitt PE, Watya S, Nalugoda F, Ssempijja V, Tobian AA, Kiwanuka N, Moulton LH, Sewankambo NK, Reynolds SJ, Quinn TC, Iga B, Laeyendecker O, Oliver AE, Wawer MJ. Male circumcision decreases acquisition and increases clearance of high-risk human papillomavirus in HIV-negative men: a randomized trial in Rakai, Uganda. J Infect Dis. 2010 May 15;201(10):1455-62.

[151] Castellsague X, Bosch FX, Munoz N, Meijer CJ, Shah KV, de Sanjose S, Eluf-Neto J, Ngelangel CA, Chichareon S, Smith JS, Herrero R, Moreno V, Franceschi S. Male circumcision, penile human papillomavirus infection, and cervical cancer in female partners. N Engl J Med. 2002 Apr 11;346(15):1105-12.

[152] Hernandez BY, Wilkens LR, Zhu X, McDuffie K, Thompson P, Shvetsov YB, Ning L, Goodman MT. Circumcision and human papillomavirus infection in men: a site-specific comparison. J Infect Dis. 2008 Mar 15;197(6):787-94.

[153] Giuliano AR, Lazcano E, Villa LL, Flores R, Salmeron J, Lee JH, Papenfuss M, Abrahamsen M, Baggio ML, Silva R, Quiterio M. Circumcision and sexual behavior: Factors independently associated with human papillomavirus detection among men in the HIM study. International Journal of Cancer. 2009 Mar 15;124(6):1251-7.

[154] Asculai SS, Weis MT, Rancourt MW, Kupferberg AB. Inactivation of herpes simplex viruses by nonionic surfactants. Antimicrob Agents Chemother. 1978 Apr;13(4): 686-90.

[155] Singh B, Utidjian HM, Cutler JC. Studies on Development of a Vaginal Preparation Providing Both Prophylaxis against Venereal Disease, Other Genital Infections and Contraception.3. In-Vitro Effect of Vaginal Contraceptive and Selected Vaginal Preparations of Candida-Albicans and Trichomonas-Vaginali. Contraception. 1972;5(5): 401-\&.

[156] Singh B, Utidjian HM, Cutler JC. Studies on Development of a Vaginal Preparation Providing Both Prophylaxis against Venereal Disease and Other Genital Infections and Contraception.2. Effect in-Vitro of Vaginal Contraceptive and Non-Contraceptive Preparations on Treponema-Pallidum and Neisseria-Gonorrhoeae. British Journal of Venereal Diseases. 1972;48(1):57-\&. 
[157] Polsky B, Baron PA, Gold JW, Smith JL, Jensen RH, Armstrong D. In vitro inactivation of HIV-1 by contraceptive sponge containing nonoxynol-9. Lancet. 1988 Jun 25;1(8600):1456.

[158] Van Damme L, Ramjee G, Alary M, Vuylsteke B, Chandeying V, Rees H, Sirivongrangson P, Mukenge-Tshibaka L, Ettiegne-Traore V, Uaheowitchai C, Karim SS, Masse B, Perriens J, Laga M. Effectiveness of COL-1492, a nonoxynol-9 vaginal gel, on HIV-1 transmission in female sex workers: a randomised controlled trial. Lancet. 2002 Sep 28;360(9338):971-7.

[159] Schaeffer DJ, Krylov VS. Anti-HIV activity of extracts and compounds from algae and cyanobacteria. Ecotoxicol Environ Saf. 2000 Mar;45(3):208-27.

[160] Buck CB, Thompson CD, Roberts JN, Müller M, Lowy DR, Schiller JT. Carrageenan is a potent inhibitor of papillomavirus infection. PLoS pathogens. 2006 Jul;2(7):e69.

[161] Skoler-Karpoff S, Ramjee G, Ahmed K, Altini L, Plagianos MG, Friedland B, Govender S, De Kock A, Cassim N, Palanee T, Dozier G, Maguire R, Lahteenmaki P. Efficacy of Carraguard for prevention of HIV infection in women in South Africa: a randomised, double-blind, placebo-controlled trial. Lancet. 2008 Dec 6;372(9654):1977-87.

[162] Roberts JN, Buck CB, Thompson CD, Kines R, Bernardo M, Choyke PL, Lowy DR, Schiller JT. Genital transmission of HPV in a mouse model is potentiated by nonoxynol-9 and inhibited by carrageenan. Nat Med. 2007 Jul;13(7):857-61.

[163] Roberts JN, Kines RC, Katki HA, Lowy DR, Schiller JT. Effect of Pap Smear Collection and Carrageenan on Cervicovaginal Human Papillomavirus-16 Infection in a Rhesus Macaque Model. Journal of the National Cancer Institute. 2011 May;103(9): 737-43.

[164] Rupp R, Rosenthal SL, Stanberry LR. VivaGel (SPL7013 Gel): a candidate dendrimer--microbicide for the prevention of HIV and HSV infection. Int J Nanomedicine. 2007;2(4):561-6.

[165] Starpharma Holdings Limited. Shareholder Upadate: May 2008. Available from: http://asx.thebull.com.au/news-history?S=SPL\&E=ASX\&Year=2008. 